\title{
A Systematic Scoping Literature Review of Publications Supporting Treatment Guidelines for Pediatric Atopic Dermatitis in Contrast to Clinical Practice Patterns
}

\author{
Elaine C. Siegfried · Jennifer C. Jaworski $\cdot$ Paola Mina-Osorio (D)
}

Received: April 20, 2018 / Published online: June 1, 2018

(C) The Author(s) 2018
Enhanced digital features To view enhanced digital features for this article go to https://doi.org/10.6084/ m9.figshare.6275408.

\section{E. C. Siegfried}

Saint Louis University and Cardinal Glennon

Children's Hospital, St. Louis, MO, USA

J. C. Jaworski

Chicago, IL, USA

\section{P. Mina-Osorio ( $\square)$}

Regeneron Pharmaceuticals Inc, Tarrytown, NY, USA

e-mail: paola.minaosorio@regeneron.com were disproportionately more publications for topical calcineurin inhibitors (TCI) compared with topical corticosteroids (TCS); however, the search interval may have biased the results toward treatments approved near the beginning of the time frame. In contrast, publications documenting clinical practice patterns reflect greater use of emollients and TCS (over TCI), as well as systemic corticosteroids. Data is relatively limited for long-term and combination treatment, treatment of severe $\mathrm{AD}$, and patients younger than 2 years of age, and completely lacking for systemic corticosteroids.

Conclusion: This scoping review demonstrates that available medical literature largely supports published guidelines for topical therapy; however, clinical practice patterns are less aligned. There is a lack of data for older, more frequently used generic treatments, including oral antihistamines, oral antibiotics, and systemic corticosteroids. Overall, literature is lacking for long-term treatment, treatment for patients younger than 2 years of age, and for systemic treatment for severe disease.

Funding: Regeneron Pharmaceuticals Inc.

Keywords: Adolescents; Atopic dermatitis; Atopic eczema; Biologic agents; Children; Infants; Systemic treatment; Topical calcineurin inhibitors; Topical corticosteroids; Topical treatment 


\section{INTRODUCTION}

Atopic dermatitis (AD) is a systemic immunemediated disease which primarily affects children with variably reported pediatric prevalence of $9-25 \%[1,2]$. There is a wide range of disease severity, and a variety of approaches to treatment. There are few US Food and Drug Administration (FDA)-approved treatments for $\mathrm{AD}$, leaving many health care providers to prescribe off-label medications.

Several recent treatment-specific systematic reviews evaluate the efficacy and/or safety of topical calcineurin inhibitors (TCIs) [3, 4], topical corticosteroids (TCS) [4], immunotherapy [5], immunosuppressants [6, 7], omalizumab [8], emollients [9, 10], phototherapy [11-14], and wet wraps [15]. The goal of this systematic scoping review was to quantitatively and qualitatively assess the volume of medical literature supporting guidelines-based treatment as well as treatment with recently approved and late-stage investigational pharmacologic and non-pharmacologic agents for $\mathrm{AD}$ in pediatric patients [1, 16-25]. Because there are no pediatric-specific $\mathrm{AD}$ treatment guidelines, we sought to evaluate how different treatment modalities have been investigated across age groups and disease severities and how these correspond to published guidelines and studies of clinical practice patterns. The results of this analysis indicate gaps in evidence supporting current clinical management.

\section{METHODS}

A literature search for "atopic dermatitis" and specific drug-related keywords was performed using Embase on 7 November, 2016. Search terms are listed in Table 1 . A review protocol does not exist. This article is based on previously conducted studies and does not contain any studies with human participants or animals performed by any of the authors.

Results were limited to those published in English after 1 January, 2005 that included newborns, infants, children, and/or adolescents. The search was supplemented with manual searches of selected meetings, which included the American Academy of Dermatology (AAD; annual and summer meetings), the American Academy of Allergy, Asthma and Immunology (AAAAI), the Society for Pediatric Dermatology (SPD)/World Congress of Pediatric Dermatology (WCPD), the European Academy of Dermatology and Venereology (EADV), the Society for Investigational Dermatology (SID)/ International Investigational Dermatology (IID), and the European Society for Pediatric Dermatology (ESPD) meetings in the previous 3 years. References from meetings other than these were not included.

Results are reported as numbers of references by study design (interventional non-comparative, interventional non-randomized comparative, randomized active-controlled, randomized placebo/vehicle-controlled, randomized untreatedcontrolled, observational prospective cohort, observational cross-sectional, observational comparative, registry, case report/series, pooled/ secondary/subgroup analysis of previously published data, retrospective chart review, retrospective cohort, and survey/interview). On the basis of keywords listed in Table 1, references were also identified by category of primary treatment investigated [TCIs, TCS, systemic immunotherapy, biologic, systemic immunosuppressant, topical phosphodiesterase 4 (PDE4) inhibitor, topical antibiotic, oral PDE4 inhibitor, topical immunotherapy, pharmacologic combination treatment, emollient, phototherapy, wet wraps, bathing, dilute bleach baths, and non-pharmacologic combination treatment]. When more than one active treatment was compared, only the primary treatment was used to categorize the reference; if a combination of treatments was used as primary treatment, the reference was categorized as "combination treatment". The potency of TCS was determined on the basis of several sources $[16,26-28]$, and clinical judgment in the case of non-marketed products; if a study included more than one TCS of different potency (e.g., medium potency for the body and low potency for face), it was counted for the highest potency TCS used. References that described clinical practice patterns were summarized separately. References regarding new data (i.e., not pooled/secondary/subgroup analysis of previously published data) were further categorized by AD severity as 
Table 1 Search terms

\begin{tabular}{|c|c|}
\hline Treatment & Search terms \\
\hline Corticosteroid & 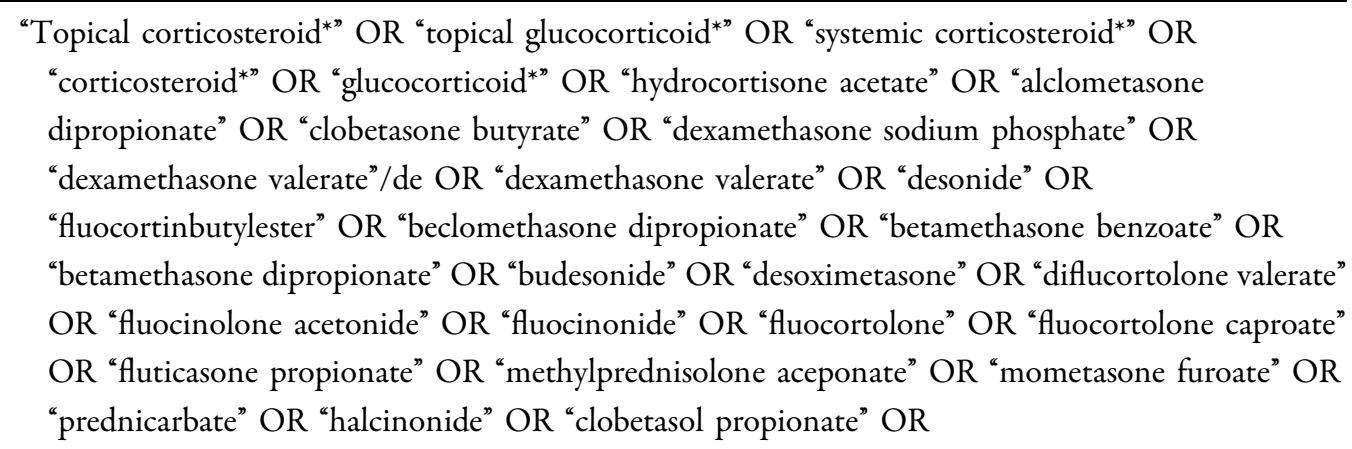 \\
\hline $\begin{array}{l}\text { Calcineurin } \\
\text { inhibitor }\end{array}$ & "Tacrolimus" OR "pimecrolimus" OR \\
\hline Immunosuppressant & $\begin{array}{l}\text { “Cyclosporine” OR cyclosporin OR "azathioprine” OR “methotrexate” OR “mycophenolate mofetil” } \\
\text { OR }\end{array}$ \\
\hline Oral antihistamine & “Oral antihistamine ${ }^{* »}$ OR \\
\hline Phototherapy & "Phototherapy" OR \\
\hline Immunotherapy & Immunotherapy OR \\
\hline Emollient & “Emollient" OR \\
\hline Wet wrap & "Physical therap*” OR "wet wrap"” OR "wet dressing*” OR \\
\hline Bathing & "Bath"” OR \\
\hline Dilute bleach baths & "Hypochlorite sodium” OR \\
\hline Antibiotic & $\begin{array}{l}\text { "Antibiotic agent" OR “beta lactam antibiotic" OR "flucloxacillin" OR "amoxicillin plus clavulanic } \\
\text { acid" OR "cephalosporin" OR }\end{array}$ \\
\hline Biologic & “Omalizumab” OR "ustekinumab" OR \\
\hline PDE4 inhibitor & “Apremilast" OR “crisaborole” OR “e6005” OR “e-6005” OR "opa-15406” OR "opa15406” \\
\hline
\end{tabular}

PDE4 phosphodiesterase 4

defined within the reference (mild was analyzed together with mild-to-moderate, and moderate was analyzed with moderate-to-severe/very severe) and pediatric age groups included in the study [newborns (up to 1 month), infants (1-12 months), children (1-12 years), and/or adolescents (13-17 years)]; studies that included patients from more than one age group were counted in both groups. Interventional trials were classified by duration of treatment, or duration of follow-up for long-acting treatments like immunotherapy and biologics.

\section{RESULTS}

A total of 1579 references were retrieved from Embase and screened for relevance (Fig. 1). The following references were excluded: those not focused on treatment (i.e., risk factors for $\mathrm{AD}$ ), those that did not specify treatment, duplicate references, encore abstracts, abstracts presenting data for which a manuscript has been published, abstracts from other meetings, nonEnglish articles, abstract supplements, retracted articles, commentaries, review articles, and 


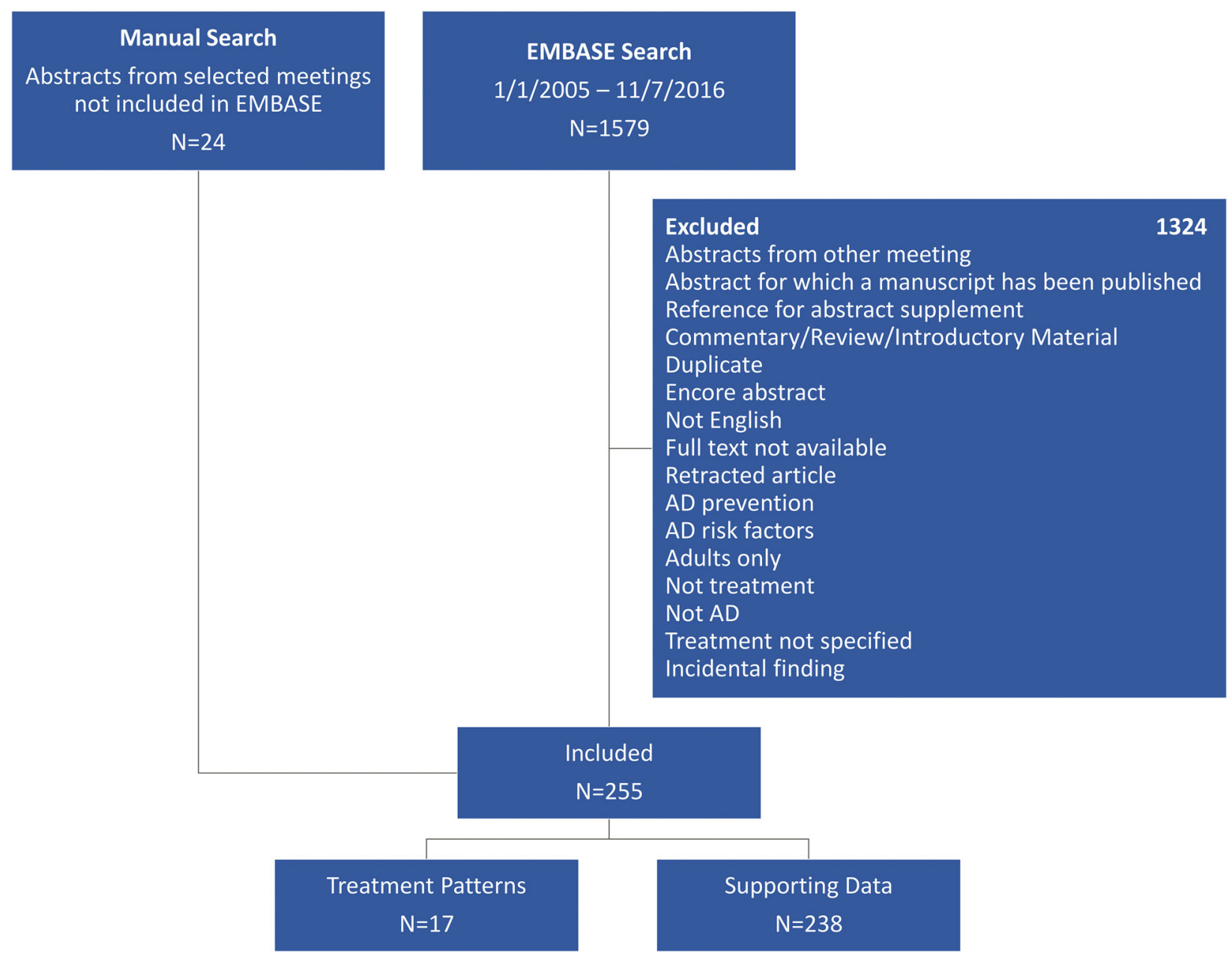

Fig. 1 PRISMA flow diagram. $A D$ atopic dermatitis

introductory articles. An additional 77 articles were not included in the analysis because they focused on treatments that are not part of current guideline-based management or new therapies: pro/prebiotics $(n=14)$; clothing $(n=10)$; traditional Chinese medicine $(n=8)$; intravenous immunoglobulin $(n=5)$; cleansing, vitamin supplements, and educational interventions ( $n=4$ each); dietary elimination and balneo/crenotherapy ( $n=3$ each); oral leukotriene inhibitors, water softeners, apheresis, and phytotherapy ( $n=2$ each); and acupuncture, topical antifungal, temperature-controlled lamellar airflow, skin acidification, peroxisome proliferator-activated receptor-alpha agonist treatment, efalizumab, etanercept, chloroquine, lipoxins, adrenergic agonist treatment, hydrocolloid dressing, homeopathy, application of human milk, and high altitude treatment $(n=1$ each). In addition, references focusing on adult patients, patient populations with mean age greater than 20 years, patient populations that were less than $40 \%$ pediatric, or prevention of $\mathrm{AD}$ were also excluded leaving 231 articles. Manual searches of abstracts from selected meetings yielded an additional 24 references, added to the 51 identified in the Embase search, for a total of 75 abstract references. This yields a total of 255 references for inclusion.

Of these, 17 assessed clinical practice patterns via prospective analysis, claims data, retrospective analysis, or surveys/interviews [29-45], and documented a wide variety of treatments used in 
clinical practice (Fig. 2). Overall, 7 of 17 papers reported emollient use by up to $96 \%$ of patients. Seven references also reported systemic corticosteroid use in $1-25 \%$ of patients.

The most frequently used study designs in this 11-year review were interventional noncomparative and randomized controlled. The most frequently investigated medical treatments were TCIs and emollients (Fig. 3).

\section{Treatments by AD Severity and Age Group}

Published pharmacologic treatment trials varied by AD severity (Fig. 4); however, AD severity was not consistently defined. A number of studies did not prespecify severity $(n=48)$ or used surrogate definitions $(n=8)$. The pattern of severities studied was similar across age groups. Mild-to-moderate or not specified/other severity was included most frequently, and the 13- to 17-year age range was investigated most often (Fig. 5).

Publications more often investigated topical treatments for mild-to-moderate $\mathrm{AD}$ and systemic treatments for more severe AD (Fig. 4). Non-pharmacologic treatments were investigated primarily in mild-to-moderate AD (Fig. 4).

Across age groups, TCIs and emollients were the treatments most frequently investigated (Fig. 6). The number of treatment modalities investigated in children (1-12 years) was greater than any other age group (Fig. 6). Few studies included treatment in infants and newborns (Fig. 6). Despite the frequency of systemic corticosteroid use in clinical practice, this analysis failed to identify any publications supporting use of this treatment.

\section{Supporting Evidence by Treatment}

\section{Topical Pharmacologic Treatments}

There were 27 references that studied TCS as primary treatment [46-72]; an additional 16 used TCS as an active comparator. Of the 27 references focusing on TCS, 2 were pooled analyses of previously published studies, 5 were case reports/series, and 3 did not assess clinical efficacy. TCS clinical efficacy studies were primarily interventional non-comparative $(n=7$ each). Other designs were utilized less often [randomized vehicle-controlled $(n=3)$, randomized active-controlled $(n=2$ and $n=4$, respectively), and randomized active-/vehiclecontrolled ( $n=1$ each)]. Studies that included infants were more often interventional noncomparative $(n=3)$ or randomized active-controlled $(n=3)$ compared with randomized vehicle-controlled $(n=1)$. The single trial that included newborns was randomized, comparing different dosing regimens. Of the active-controlled studies, 1 was once versus twice daily treatment, 1 was proactive versus reactive treatment, 1 was soak-and-smear vs dry skin application, and 1 was application before versus after emollient, all with the same TCS. The only active- and vehicle-controlled trial compared different formulations of the same TCS. Among the 20 interventional TCS studies, 1 used lowest potency, 5 used low potency, 2 used lowermedium potency, 11 used medium potency, none used high potency, and 1 used very high potency TCS. Of these, two of the medium potency TCS studies included a low potency TCS for the face and other sensitive skin areas (Table 2). More studies of mild-to-moderate disease focused on older age groups (Table 2).

There were 59 references with TCIs as primary treatment [73-131]; an additional 5 references used TCIs as an active comparator. Of the 59 references, 9 were pooled/secondary/post hoc analyses of previously published studies and 7 studies did not assess clinical efficacy. The greatest numbers of TCI clinical efficacy studies in adolescents, children, and/or infants were interventional non-comparative $(n=12, n=16$, $n=6$, respectively) or randomized vehicle-controlled $(n=8, n=12, n=3)$ compared with randomized active-controlled $(n=9, n=10$, $n=3)$. Of the active-controlled studies, 9 were versus TCS, 1 was versus the same TCI using different doing regimen, 1 was versus another TCI, and 2 were versus emollient/device cream.

The majority of references (10/16, 63\%) supporting topical PDE4 inhibitors were pooled or post hoc analyses [132-147]. Of the remaining references, 3 were randomized vehicle-controlled, 2 were interventional non-comparative, and 1 was randomized active-controlled versus 


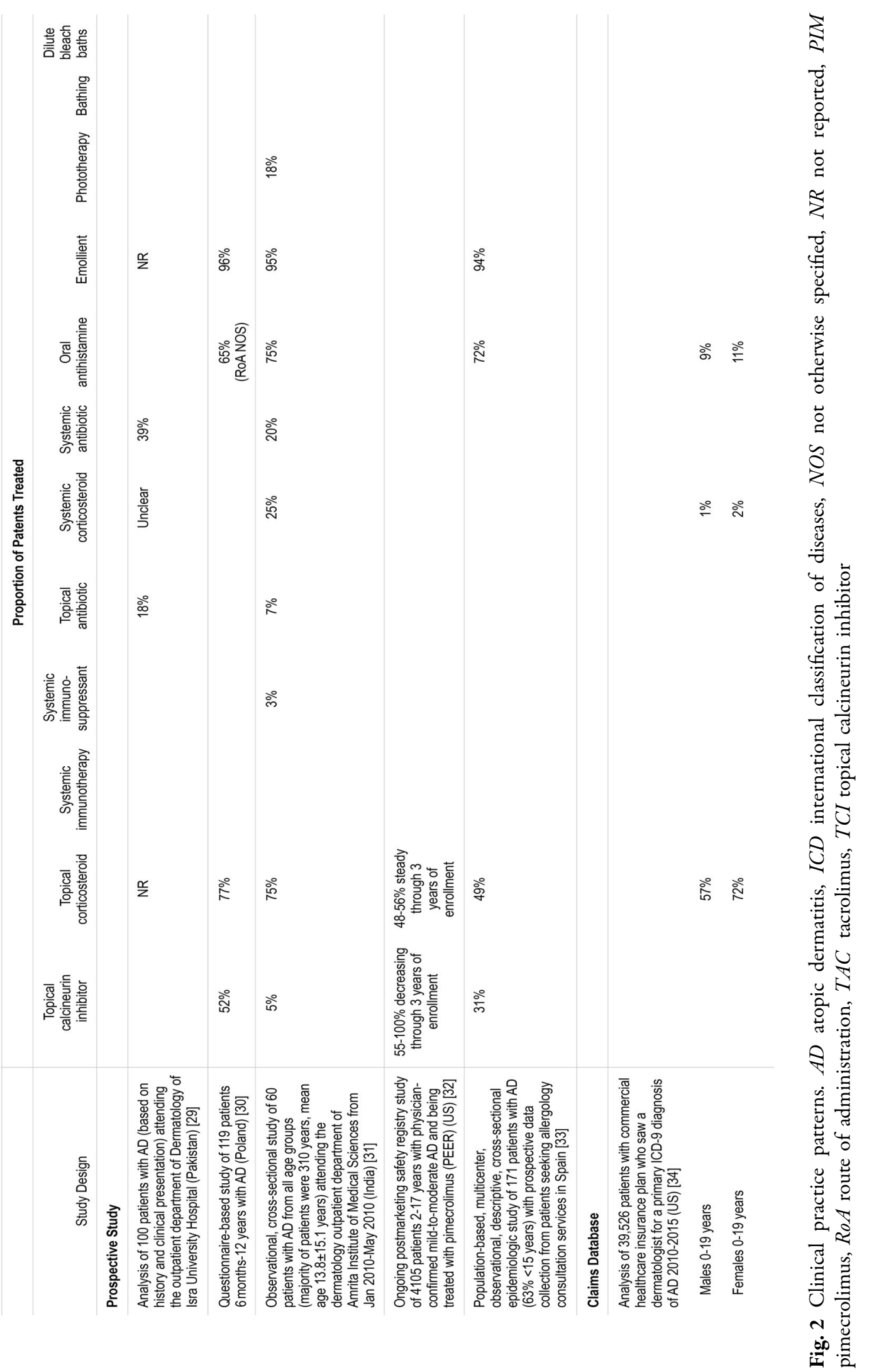




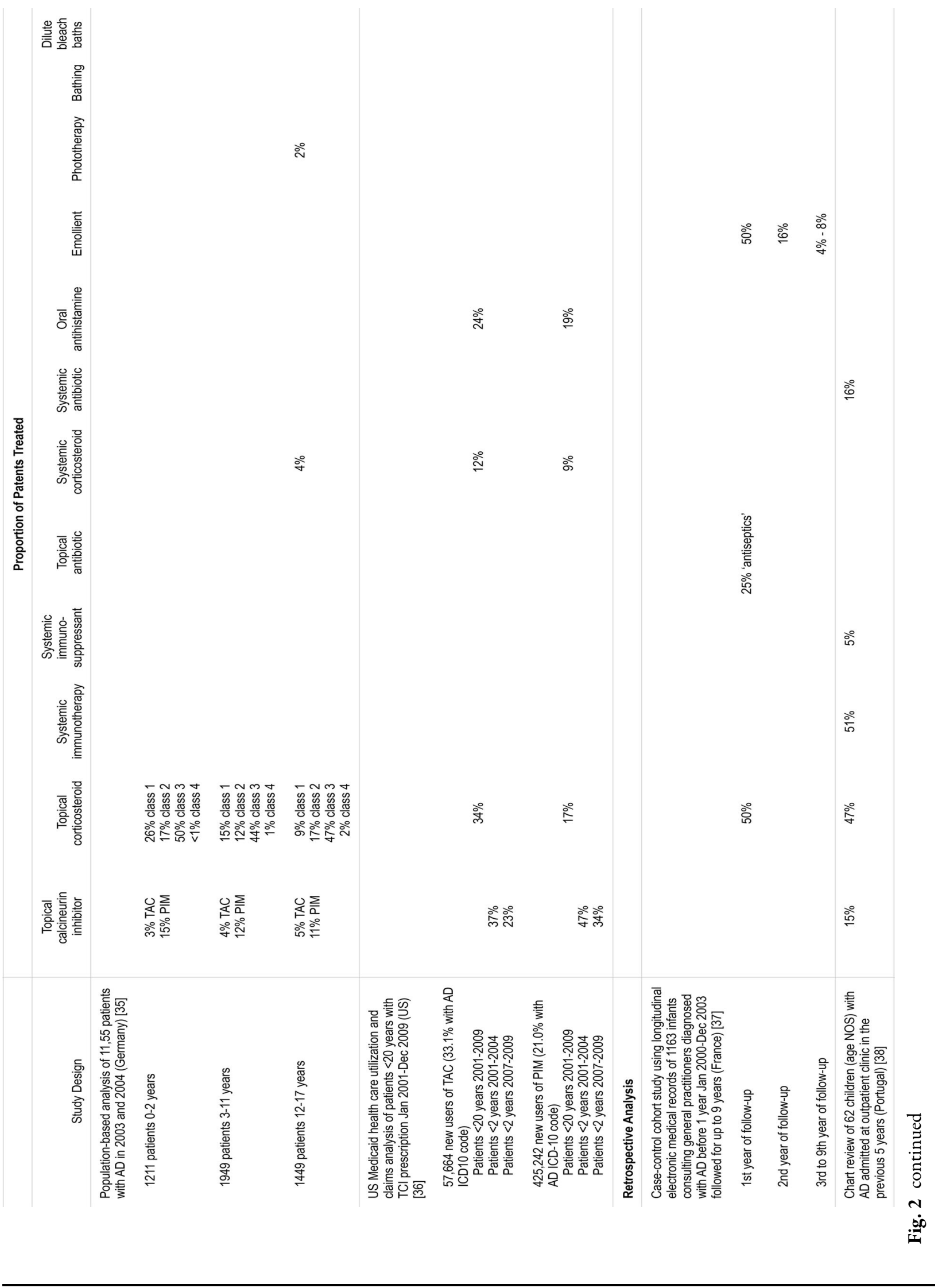




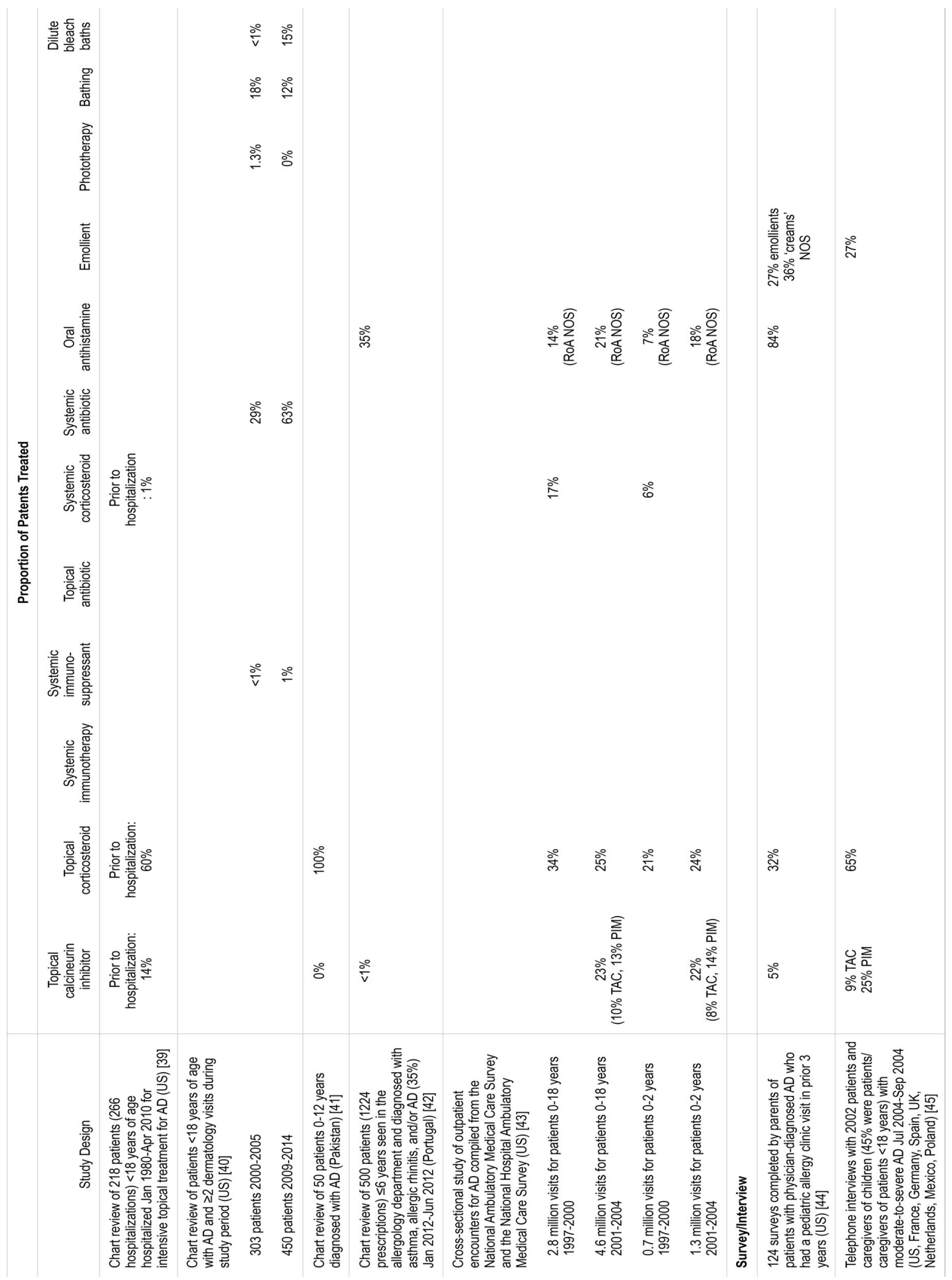

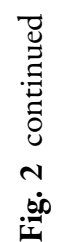


A

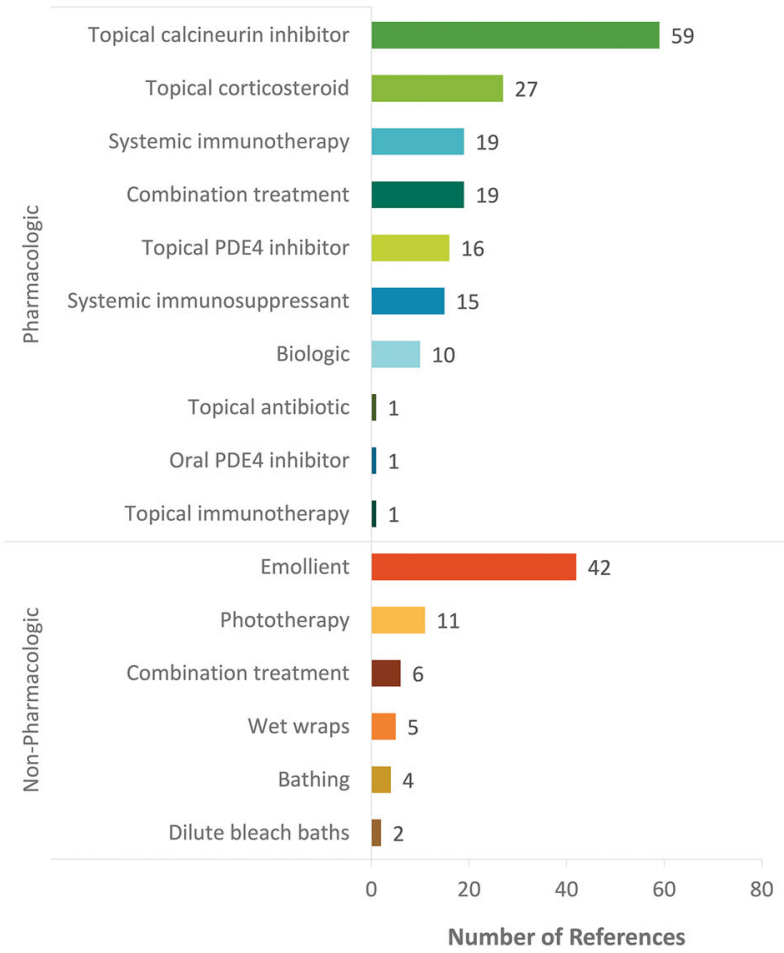

B

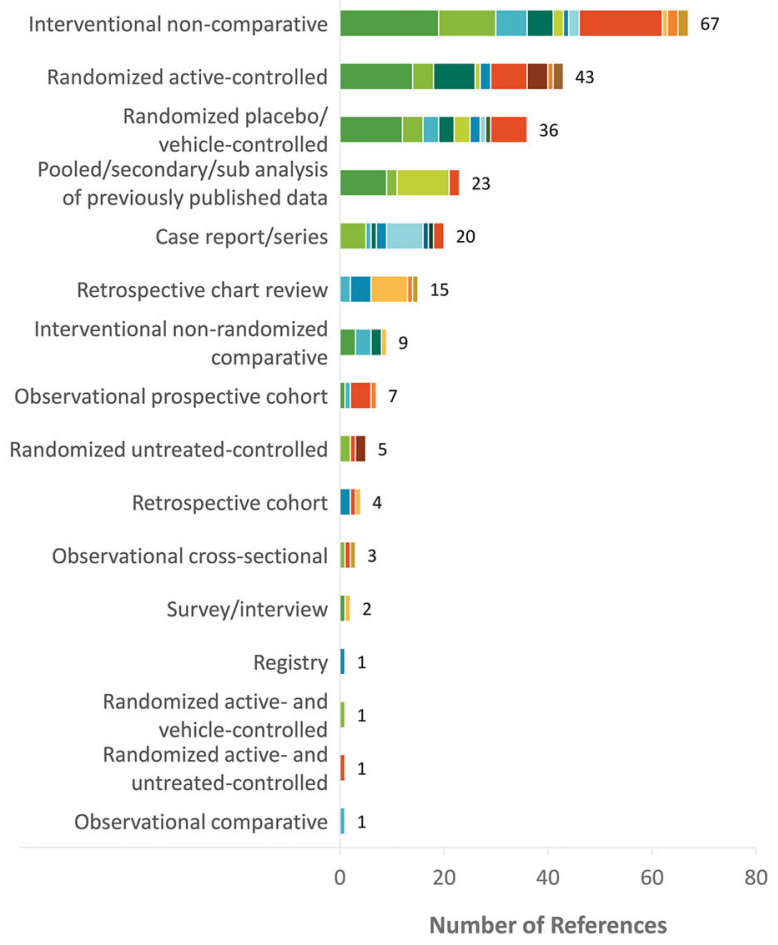

Fig. 3 Number of references by primary investigated treatment $(\mathbf{a})$ and study design $(\mathbf{b} ; n=238)$. The same color coding used in a was used to indicate primary treatment investigated in $\mathbf{b}$, and in all other figures. PDE4 phosphodiesterase 4

A

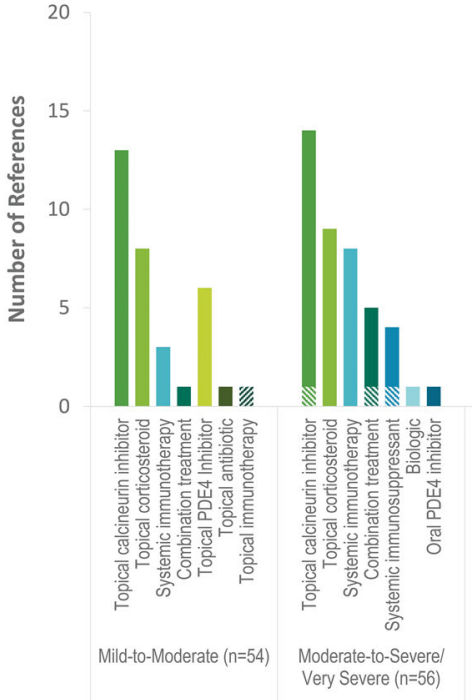

B

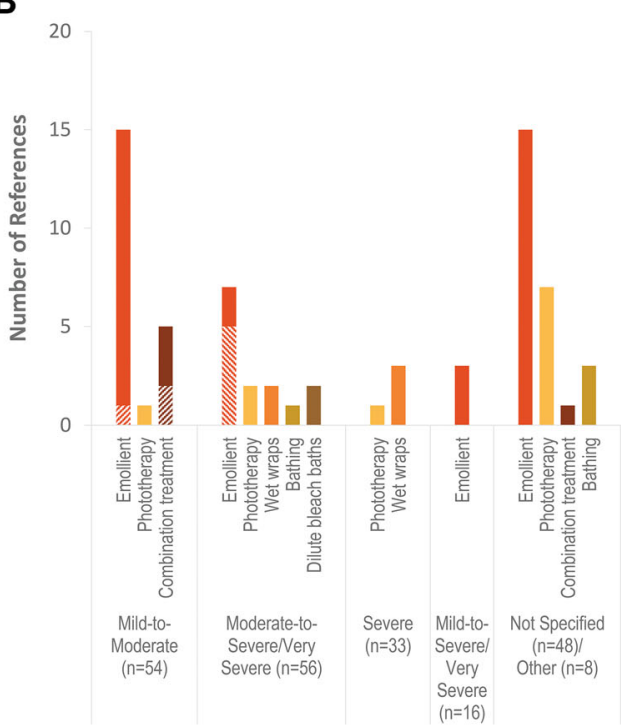

Fig. 4 Number of references investigating pharmacologic (a) and non-pharmacologic (b) treatments by AD severity $(n=215)$. Solid filled bars represent ranges listed on the $\mathrm{x}$-axis; pattern filled bars represent the "mild" $(n=4)$ or "moderate" $(n=8)$ subset of the indicated ranges. PDE4 phosphodiesterase 4 


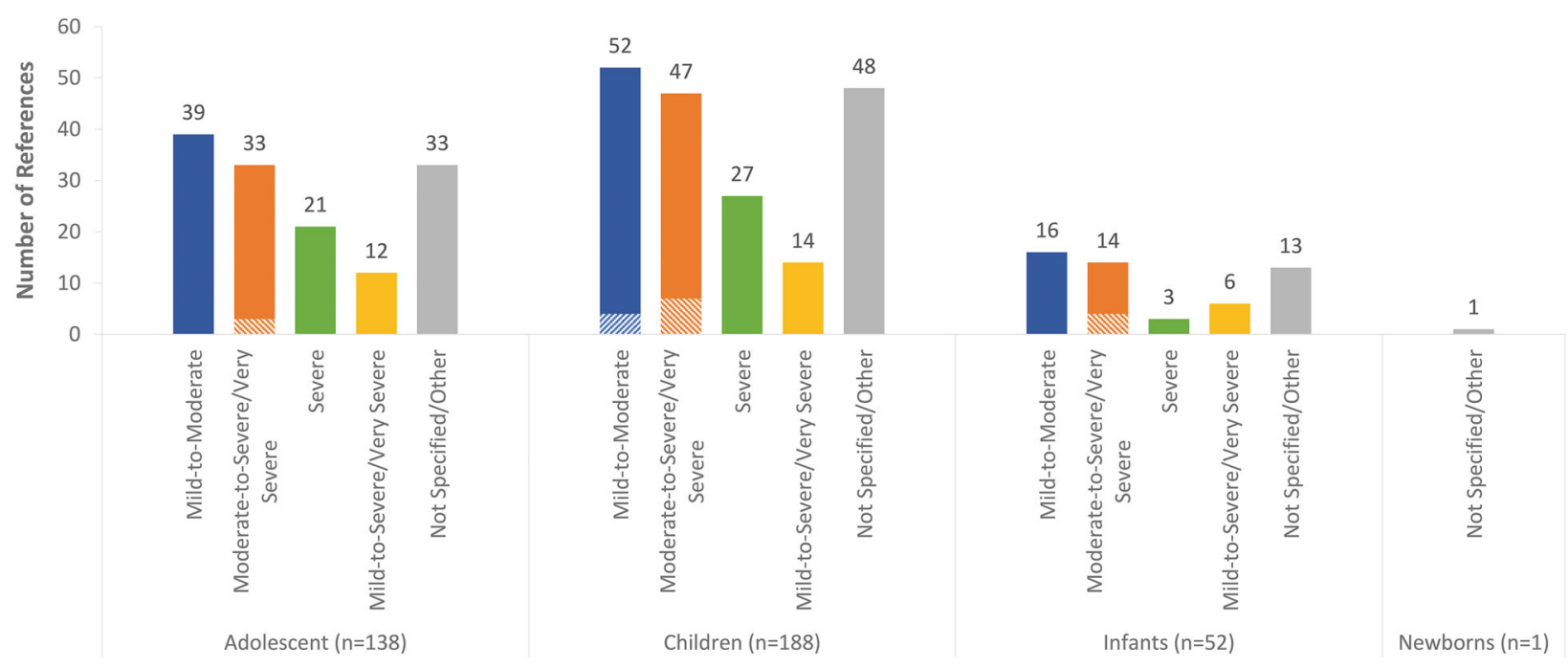

Fig. 5 Number of references by AD severity and age group $(n=215)$. Solid filled bars represent ranges listed on the $\mathrm{x}$-axis; pattern filled bars represent the "mild" $(n=4)$ or "moderate" $(n=8)$ subset of the indicated ranges

A

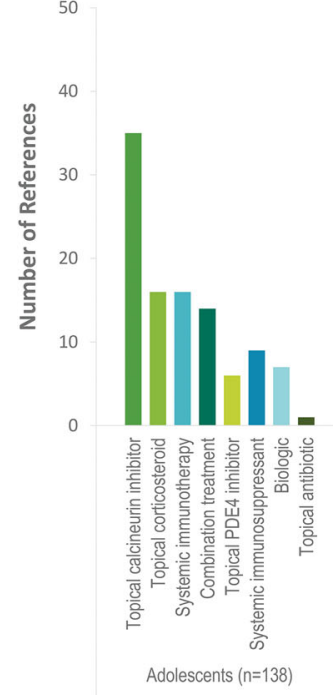

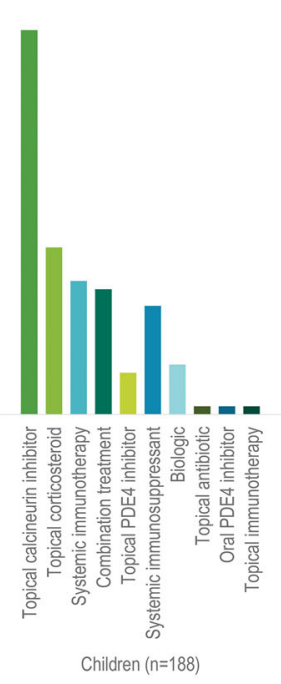

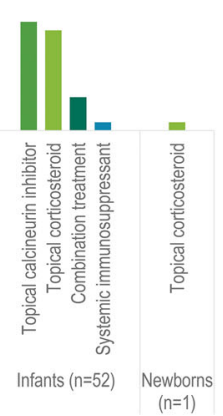

B
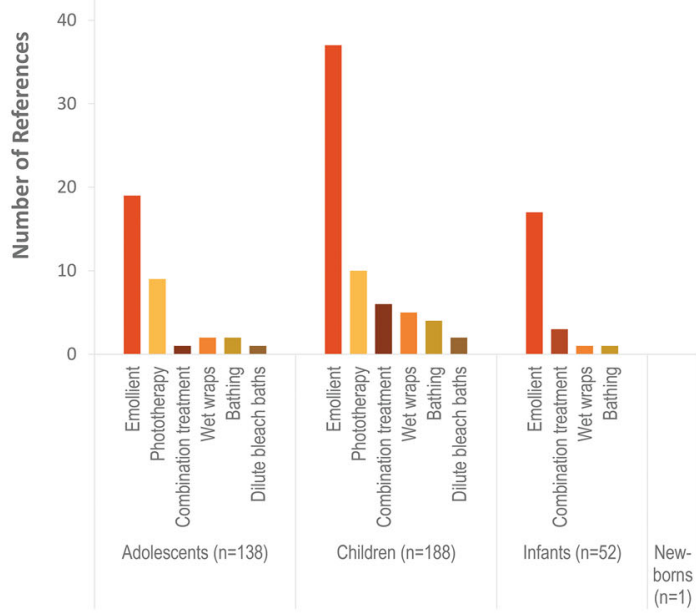

Fig. 6 Number of references investigating pharmacologic (a) and non-pharmacologic (b) treatments by age group $(n=215)$. PDE4 phosphodiesterase 4

the same topical PDE4 inhibitor using a different dosing regimen.

Topical combination treatments included TCS-antibiotic $\quad(n=4), \quad$ TCI-phototherapy $(n=1)$, TCS-TCI $(n=6)$, TCS-emollient $(n=3)$, and TCS-wet wrap $(n=2)$ [148-163]. There was 1 case series. The remaining studies were interventional non-comparative $(n=3)$, randomized vehicle-controlled $(n=3)$, or randomized active-controlled $(n=9 ; 8$ were vs monotherapy and 1 was vs emollient) and included adolescents $(n=11)$, children $(n=13)$, and infants $(n=4)$. 


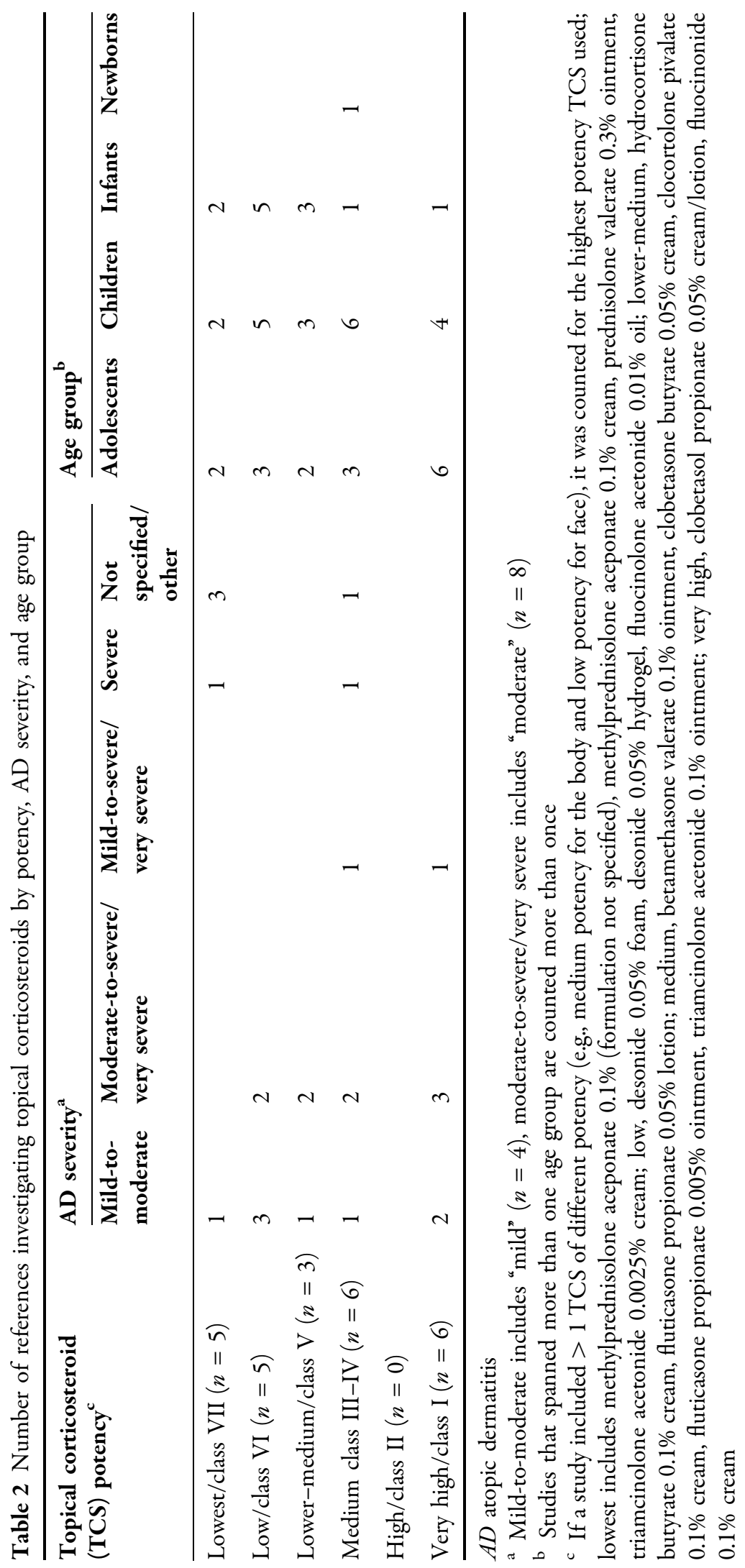


In addition, topical antibiotic treatment was the subject of a randomized vehicle-controlled study in children and adolescents [164], and topical immunotherapy with Streptococcus pyogenes ointment was the topic of a case study in a child [165].

Topical pharmacologic treatments were the most frequently investigated. Overall, evidence was high level and covered a wide range of age groups. Notably, the only reference to include newborns was a TCS trial.

\section{Systemic Pharmacologic Treatments}

There were 15 references that included one or more systemic immunosuppressant agents as primary treatment [166-180]; 1 additional reference used a systemic immunosuppressant as an active comparator. Medications included azathioprine $(n=7), \quad$ cyclosporine $(n=6)$, cyclosporine-glucosamine combination $(n=2)$, methotrexate $(n=3)$, and mycophenolate mofetil $(n=3)$. Of the 15 references, 2 were case reports/series, 6 were retrospective chart reviews/cohorts, and 1 was a registry. Of the remaining 6 studies, all assessed clinical efficacy-1 was interventional non-comparative (including children and adolescents), 2 were randomized placebo-controlled ( 1 in adolescents, 1 in children), 2 were randomized activecontrolled (1 versus a different systemic immunosuppressant in children and 1 combination systemic immunosuppressant therapy versus monotherapy in adolescents).

There were 19 references that used systemic immunotherapy as primary treatment [181-199] including subcutaneous $(n=12)$, sublingual $(n=4)$, or oral antigen administration $(n=1)$, and intradermal $(n=1)$ or subcutaneous Mycobacterium vaccae $(n=1)$. Of these, 1 was a case report and 2 were retrospective chart reviews. Of the remaining 16 studies, 15 assessed clinical efficacy. Of these, 6 were interventional non-comparative (1 in adolescents, 1 in children, 4 included both groups), 3 were randomized placebo-controlled ( 1 in adolescents, 1 in children, 1 included both groups), 4 were untreated-controlled (all included children and adolescents), and 2 were active-controlled (1 in adolescents, 1 included both groups). Of the active controlled trials, both were versus conventional multimodal therapy. There were no immunotherapy trials in infants or newborns.

There were 10 references that included omalizumab $(n=9)$ or ustekinumab $(n=1)$ biologic treatment [200-209]. Of these, only 3 were interventional: 2 non-comparative (1 in adolescents, 1 in children and adolescents) and 1 randomized placebo-controlled in children and adolescents. The other 7 were case reports/ series.

Systemic combination treatments included immunotherapy-immunomodulator $(n=3)$ and immunotherapy-immunosuppressant $\quad(n=1)$ combinations [210-213]. They were interventional non-comparative $(n=2)$ and interventional non-randomized comparative $(n=2)$ and included children and adolescents $(n=3)$ or adolescents alone $(n=1)$.

In addition, there was a case report of oral PDE4 inhibitor treatment in a child [214].

Systemic treatments were investigated less frequently than topical treatments. The level of evidence in these references was lower than those in references about topical treatments. There was only 1 paper among 60 that included infants; none included newborns.

\section{Non-pharmacologic Management}

There were 53 references addressing first-line skin care as primary treatment [215-267], including 42 papers assessing emollients (an additional 4 used emollient as an active comparator), 4 assessing bathing (an additional 2 references used bathing as an active comparator), 2 assessing dilute bleach baths, and 5 assessing emollient-cleanser combinations. Of these 53 references, 2 were case reports/series and 2 were pooled/secondary/subgroup analyses of previously published data. All but one of the remaining papers assessed efficacy including 2 retrospective chart reviews/cohorts, 6 observational studies, 17 interventional non-comparative studies, 10 randomized untreated/ vehicle-controlled studies, 12 randomized active-controlled studies, and 1 randomized active- and untreated-controlled study. Of the trials that included an active comparator, 2 were versus TCS, 5 were versus a different emollient, 2 were versus bathing, and 3 were versus 


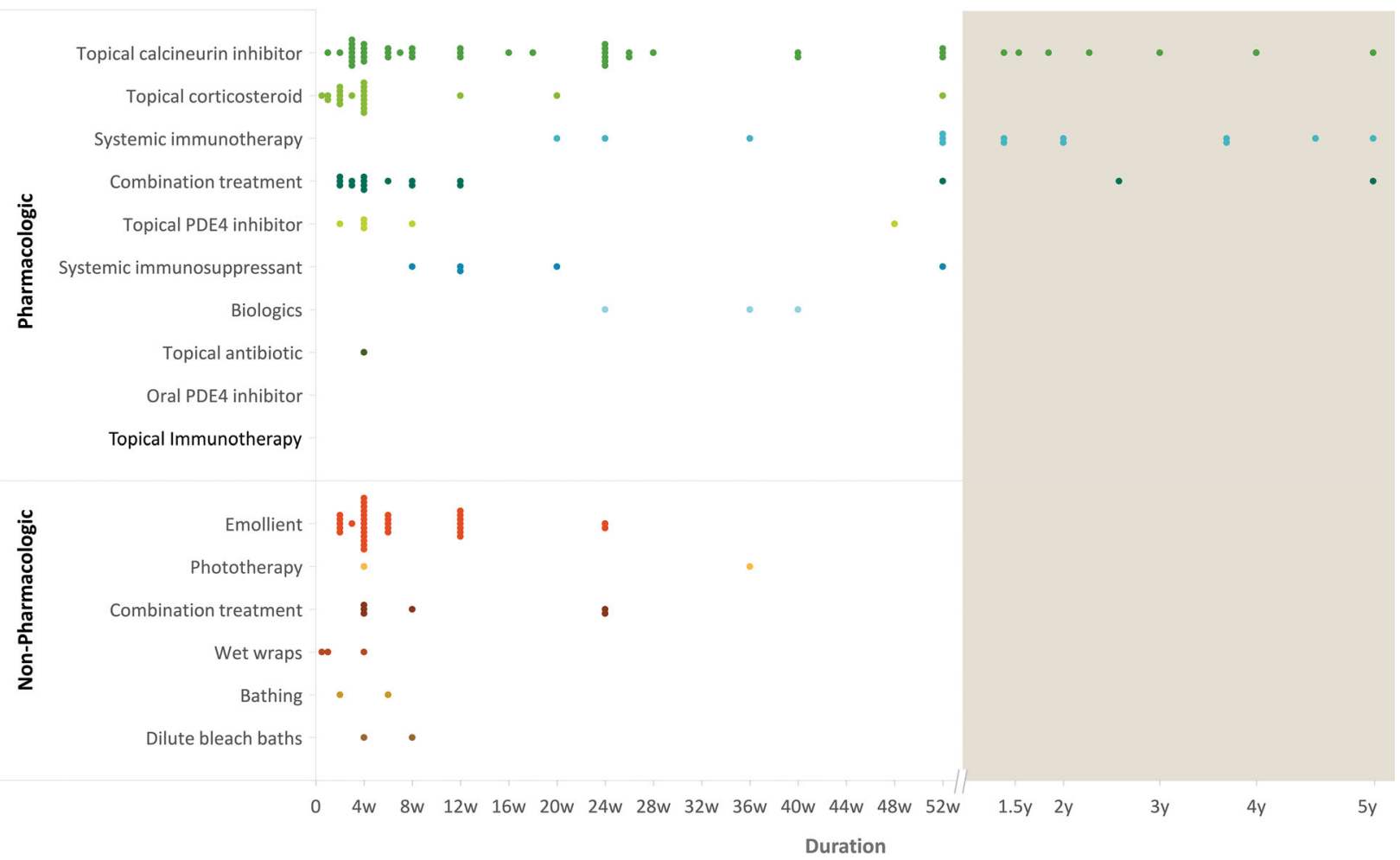

Fig. 7 Duration of treatment for short-acting treatments/duration of follow-up for long-acting treatments in interventional studies $(n=162)$. Duration of

monotherapy. First-line skin care efficacy studies primarily included children $(n=48)$.

A total of 5 references assessed wet wrap therapy as primary treatment [268-272]. Of these 1 was a retrospective chart review, 1 was an observational prospective cohort, and 2 were interventional non-comparative. The remaining reference was a randomized active-controlled study versus conventional treatment in children and infants.

There were 11 references assessing phototherapy as primary treatment [273-283]. The majority $(7 / 11,64 \%)$ were retrospective chart reviews. One additional reference included phototherapy as an active comparator.

Emollients were the second most investigated treatment. Overall, published studies of non-pharmacologic treatments included all age groups, except newborns. References treatment/follow-up could not be determined for 1 study published as an abstract. PDE4 phosphodiesterase 4, $w$ weeks, $y$ years

investigating emollients and other skin care included high level evidence, while references investigating wet wrap therapy and phototherapy had lower level evidence.

\section{Treatments and Interventional Trial Evidence by Duration of Treatment}

Out of the 162 interventional studies, 106 $(65 \%)$ were less than 12 weeks in duration (Fig. 7). Only TCIs, TCS, systemic immunotherapy, and pharmacologic combination treatment have been investigated for more than 52 weeks (Fig. 7). All TCS and TCI studies that were 24 weeks or longer used intermittent (less than daily treatment) or proactive (treating at first signs or symptoms of a flare) treatment (Fig. 7). 


\section{DISCUSSION}

The results of our analysis largely reflect current $\mathrm{AD}$ treatment guidelines [1, 16-21], and the quality of evidence supporting the use of these treatments is high (including randomized controlled trials). The relatively large number of references investigating emollient treatment and the high prevalence of emollient use reported in clinical practice (up to $96 \%$; Fig. 2) are indirect indicators that first-line management recommendations are being widely implemented.

The highest proportion of published literature in this analysis focused on the use of TCIs, likely reflecting the search interval. Topical tacrolimus was approved by the FDA in 2000, and pimecrolimus in 2001, 3 years prior to the search start date. One year into the search interval, substantial controversy focused on the theoretical risk of TCI-related lymphoma and a Boxed Warning. The number of references supporting the use of TCS is smaller than expected and more focused on mild-to-moderate disease and older age groups (Fig. 3). This may also be related to the search interval, beginning decades after widespread, "grandfathered" use of these medications. It could also reflect comparatively limited funding for clinical research to study older, generic drugs, or changes in treatment patterns over time [284].

The potencies of TCS and durations of treatment used in clinical trials reflect guideline recommendations to use the lowest potency agent for the shortest time period that will control symptoms, but long-term studies of TCS are lacking. Published studies of TCIs focus more on the safety and efficacy of monotherapy than as guidelines-directed long-term maintenance, but include data on intermittent use for up to 5 years $[119,285]$.

Current guidelines also recommend other options for moderate-to-severe AD including wet wrap therapy (with or without TCS), phototherapy, or systemic immunosuppressants (cyclosporine, azathioprine, or methotrexate, with mycophenolate mofetil as an alternative). These recommendations are also reflected in reports of clinical practice and the medical literature, although the number of references identified and level of evidence in those references are low (Fig. 3). This is not unexpected as these treatments are associated with safety concerns and limited to use in a subset of patients with severe AD. However, the high impact of severe $\mathrm{AD}$ represents a significant unmet need that deserves additional study.

Systemic antimicrobials, topical antibiotics, and other antiseptic measures are discussed but not recommended by the guidelines, except for oral antivirals/antibiotics and dilute bleach baths in patients with $\mathrm{AD}$ who have clinical signs of secondary infection. For patients who experience frequent bacterial infections, guidelines suggest that dilute bleach baths be considered as a maintenance treatment. The range of systemic antibiotic use among reports of clinical practice was wide (16-63\%; Fig. 2). This likely reflects the lack of well-accepted clinical and laboratory biomarkers to define infection, rather than colonization, as well as the shortterm improvement commonly observed after treatment with systemic anti-staphylococcal antibiotics [286]. However, high-level evidence supporting the use of systemic antibiotics is lacking, and a small meta-analysis recommends against this treatment [286].

Guidelines also suggest that sedating oral antihistamines may be useful, especially in the context of interrupted sleep. Like use of systemic antibiotics, the range of published practice patterns is wide (7-84\%; Fig. 2), possibly reflecting lack of evidence and potential adverse effects [287].

The AAD guidelines recommend avoiding systemic corticosteroids for $\mathrm{AD}$, while the AAAAI/American College of Allergy, Asthma, and Immunology (ACAAI), and European guidelines caution against their use, especially on a long-term basis. In accordance with these guidelines, our search strategy did not identify any studies that specifically investigated the use of systemic corticosteroids, although surprisingly their use ranged from $1-25 \%$ in reports of clinical practice (Fig. 2).

Several references focused on the use of systemic immunotherapy, many of which use higher level interventional evidence. The AAD guidelines do not recommend allergen-specific immunother- 
apy because of insufficient evidence, while the AAAAI/ACAAI and European guidelines suggest that it can be useful in selected patients.

Biologic therapy is discussed but not recommended by any current guideline because of insufficient evidence. There were a few references regarding use of biologic agents in pediatric patients, with only one reporting higher level evidence.

Regarding patient age groups and AD severity, there was only one reference on AD treatment in newborns and few references with high quality evidence to support treatment of severe AD using systemic agents. Although recent publications have investigated the role of emollients in preventing atopic dermatitis in newborns, they did not meet the inclusion criteria for this systematic review and were not included in this analysis [288, 289].

We and others [290] have found that the definitions of mild, moderate, and severe used in clinical trials often overlap and many trials use a range of severity (i.e., mild-to-moderate or moderate-to-severe). This lack of standardization precludes comparative effectiveness analysis of available data. There is a general need for a better definition of AD severity to guide clinical use. For example, topical tacrolimus is FDA-approved for moderate-to-severe AD [291]; however, severe $\mathrm{AD}$ often requires systemic therapy.

There is also a striking lack of medical literature for long-term use of many of the treatments included in this analysis. The only topical treatment that has been studied for longer than 1 year is TCI and the only systemic treatment is immunotherapy, which is not recommended by current guidelines for routine treatment. Given the chronic nature of $\mathrm{AD}$ and the need for ongoing maintenance treatment, long-term data is critical for making sound treatment decisions, especially for pediatric patients who are more susceptible to developmental effects and systemic exposure to topical treatments.

This scoping review expands on the results of a recent related publication; Nankervis et al. [292] assessed the quality of systematic reviews and randomized controlled trials for AD treatments in patients of all ages. Our analysis included additional primary data sources (abstracts, chart reviews, case reports, and other non-randomized data) because in the absence of high level evidence in pediatric patients, dermatologists often rely on these primary data sources when making clinical decisions regarding their patients. Including this diversity of publication types reflects "real-world" clinical practice, but limits our ability to assess the quality and outcomes of the references included in this analysis. However, the lack of a central database of conference abstracts precludes inclusion of data from all possibly relevant meetings, and some important meetings may have been inadvertently overlooked in our search.

\section{CONCLUSIONS}

In summary, treatments investigated in published medical literature include those recommended in current treatment guidelines; however, clinical practice pattern publications include a scope of therapies not supported by high level evidence or current treatment guidelines. This may be related to the fact that clinical practice patterns are often not completely evidence-based, but driven by medical training, individual experience, and institutional "norms". This makes change difficult and also delays and interferes with introduction of innovative treatments into guidelines and practice [293]. Finally, standardized data are needed to support the treatments that are actually used in clinical practice, especially those used in younger children and for longterm treatment and severe disease.

\section{ACKNOWLEDGEMENTS}

Funding. This work was funded by Regeneron Pharmaceuticals Inc. Article processing charges were funded by Regeneron Pharmaceuticals Inc. Data collection and analysis, manuscript development, and the decision to submit the manuscript were independent of the funding source. 
Medical Writing and/or Editorial Assistance. Ferdinando Giacco, PhD, of Excerpta Medica, performed the Embase search and initial reference screening under the direction of Ronald van Olffen, PhD, also of Excerpta Medica, and with financial support from Regeneron Pharmaceuticals Inc. The authors thank Yufang $\mathrm{Lu}, \mathrm{MD}, \mathrm{PhD}$, Executive Director, Immunology Medical Affairs at Regeneron Pharmaceuticals Inc, for her assistance with the development and review of the manuscript and Lucy Musielak-Stevanovic for her graphic design assistance.

Authorship. All named authors meet the International Committee of Medical Journal Editors (ICMJE) criteria for authorship for this article, take responsibility for the integrity of the work as a whole, and have given their approval for this version to be published.

Disclosures. Elaine Siegfried is an employee of Saint Louis University. She has served as principal investigator for clinical trials conducted by Regeneron Pharmaceuticals Inc. and Anacor Pharmaceuticals (now Pfizer Inc.); all monies were paid directly to her institution. She has served as a consultant for Pfizer Inc. and Dermavant Sciences and as member of the data safety monitoring board for GlaxoSmithKline plc. She did not receive financial compensation for her work on this manuscript. She provided clinical perspective, contributed substantially to the analysis and interpretation of data, critically reviewed each draft, and approved the final version for submission. Jennifer Jaworski was an employee of Prescott Medical Communications Group (Chicago, IL, USA) during the preparation of this manuscript; however, this work was completed independent of her employment. She received financial compensation for her work as a medical writer on this manuscript from Regeneron Pharmaceuticals Inc. She performed manual searches of selected meetings, the majority of reference screening, analysis of included references, wrote the first draft of the manuscript, and approved final version for submission. Paola Mina-Osorio is an employee of Regeneron Pharmaceuticals Inc; however, the opinions expressed in this article do not reflect the views of the company and the data presented is not related to any of the company's investigational or approved products. She designed the searches, provided substantial contributions to the analysis and interpretation of data, critically reviewed each draft, and approved the final version for submission.

Compliance with Ethics Guidelines. This article is based on previously conducted studies and does not contain any studies with human participants or animals performed by any of the authors.

Data Availability. Data sharing not applicable to this article as no datasets were generated or analyzed during the current study.

Open Access. This article is distributed under the terms of the Creative Commons Attribution-NonCommercial 4.0 International License (http://creativecommons.org/licenses/ by-nc/4.0/), which permits any noncommercial use, distribution, and reproduction in any medium, provided you give appropriate credit to the original author(s) and the source, provide a link to the Creative Commons license, and indicate if changes were made.

\section{REFERENCES}

1. Eichenfield LF, Tom WL, Chamlin SL, et al. Guidelines of care for the management of atopic dermatitis: section 1. Diagnosis and assessment of atopic dermatitis. J Am Acad Dermatol. 2014;70(2):338-51.

2. Silverberg JI, Silverberg NB. Childhood atopic dermatitis and warts are associated with increased risk of infection: a US population-based study. J Allergy Clin Immunol. 2014;133(4):1041-7.

3. Chen SL, Yan J, Wang FS. Two topical calcineurin inhibitors for the treatment of atopic dermatitis in pediatric patients: a meta-analysis of randomized clinical trials. J Dermatol Treat. 2010;21(3):144-56.

4. Siegfried EC, Jaworski JC, Kaiser JD, et al. Systematic review of published trials: long-term safety of topical corticosteroids and topical calcineurin inhibitors in pediatric patients with atopic dermatitis. BMC Pediatr. 2016;16:75. 
5. Tam H, Calderon MA, Manikam L, et al. Specific allergen immunotherapy for the treatment of atopic eczema. Cochrane Database Syst Rev. 2016;2:CD008774.

6. Schmitt J, Schmitt N, Meurer M. Cyclosporin in the treatment of patients with atopic eczema-a systematic review and meta-analysis. J Eur Acad Dermatol Venereol. 2007;21(5):606-19.

7. Schram ME, Borgonjen RJ, Bik CM, et al. Off-label use of azathioprine in dermatology: a systematic review. Arch Dermatol. 2011;147(4):474-88.

8. Matin N, Tabatabaie O, Falsaperla R, et al. Efficacy and safety of omalizumab in paediatric age: an update of literature data. J Biol Regul Homeost Agents. 2016;30(2):579-84.

9. Micali G, Paterno V, Cannarella R, et al. Evidencebased treatment of atopic dermatitis with topical moisturizers. G Ital Dermatol Venereol. 2018;153(3):396-402.

10. van Zuuren EJ, Fedorowicz Z, Christensen R, et al. Emollients and moisturisers for eczema. Cochrane Database Syst Rev. 2017;2:CD012119.

11. Garritsen FM, Brouwer MW, Limpens J, et al. Photo(chemo)therapy in the management of atopic dermatitis: an updated systematic review with implications for practice and research. Br J Dermatol. 2014;170(3):501-13.

12. Perez-Ferriols A, Aranegui B, Pujol-Montcusi JA, et al. Phototherapy in atopic dermatitis: a systematic review of the literature. Actas Dermosifiliogr. 2015;106(5):387-401.

13. Dogra S, Mahajan R. Phototherapy for atopic dermatitis. Indian J Dermatol Venereol Leprol. 2015;81(1):10-5.

14. Gambichler T, Breuckmann F, Boms S, et al. Narrowband UVB phototherapy in skin conditions beyond psoriasis. J Am Acad Dermatol. 2005;52(4):660-70.

15. Devillers AC, Oranje AP. Efficacy and safety of 'wetwrap' dressings as an intervention treatment in children with severe and/or refractory atopic dermatitis: a critical review of the literature. Br J Dermatol. 2006;154(4):579-85.

16. Eichenfield LF, Tom WL, Berger TG, et al. Guidelines of care for the management of atopic dermatitis: section 2. Management and treatment of atopic dermatitis with topical therapies. J Am Acad Dermatol. 2014;71(1):116-32.

17. Sidbury R, Davis DM, Cohen DE, et al. American Academy of Dermatology. Guidelines of care for the management of atopic dermatitis: section 3. Management and treatment with phototherapy and systemic agents. J Am Acad Dermatol. 2014;71(2):327-49.

18. Sidbury R, Tom WL, Bergman JN, et al. Guidelines of care for the management of atopic dermatitis: section 4. Prevention of disease flares and use of adjunctive therapies and approaches. J Am Acad Dermatol. 2014;71(6):1218-33.

19. Schneider L, Tilles S, Lio P, et al. Atopic dermatitis: a practice parameter update 2012. J Allergy Clin Immunol. 2013;131(2):295-9 (299.e1-27).

20. Ring J, Alomar A, Bieber T, for the European Dermatology Forum (EDF), and the European Academy of Dermatology and Venereology (EADV), the European Task Force on Atopic Dermatitis (ETFAD), European Federation of Allergy (EFA), the European Society of Pediatric Dermatology (ESPD), and the Global Allergy and Asthma European Network (GA2LEN), et al. Guidelines for treatment of atopic eczema (atopic dermatitis) Part I. J Eur Acad Dermatol Venereol. 2012;26(8):1045-60.

21. Ring J, Alomar A, Bieber T, for the European Dermatology Forum (EDF), and the European Academy of Dermatology and Venereology (EADV), the European Task Force on Atopic Dermatitis (ETFAD), European Federation of Allergy (EFA), the European Society of Pediatric Dermatology (ESPD), and the Global Allergy and Asthma European Network (GA2LEN), et al. Guidelines for treatment of atopic eczema (atopic dermatitis) Part II. J Eur Acad Dermatol Venereol. 2012;26(9):1176-93.

22. Eichenfield LF, Stein Gold LF. Addressing the immunopathogenesis of atopic dermatitis: advances in topical and systemic treatment. Semin Cutan Med Surg. 2017;36(2 Suppl 2):S45-8.

23. Paller AS, Kabashima K, Bieber T. Therapeutic pipeline for atopic dermatitis: end of the drought? J Allergy Clin Immunol. 2017;140(3):633-43.

24. Honda T, Nomura T, Kabashima K. Advances in atopic dermatitis and urticarial in 2016. J Allergy Clin Immunol. 2017;140(2):369-76.

25. Lauffer F, Ring J. Target-oriented therapy: emerging drugs for atopic dermatitis. Expert Opin Emerg Drugs. 2016;21(1):81-9.

26. Arana A, Wentworth CW, Rivero E, et al. Lymphoma among patients with atopic dermatitis treated with topical corticosteroids (TCS) and/or topical calcineurin inhibitors (TCIs). Pharmacoepidemiol Drug Saf. 2010;19(Suppl 1):S12.

27. Jacob SE, Steele T. Corticosteroid classes: a quick reference guide including patch test substances and 
cross-reactivity. J Am Acad Dermatol. 2006;54(4):723-7.

28. World Health Organization. Classification of topical corticosteroids. In: WHO model prescribing information: drugs used in skin diseases. Geneva: World Health Organization; 1997. p. 117-8.

29. Rajar UDM, Kazi N, Kazi SAF. The profile of atopic dermatitis in out patient department of dermatology Isra University Hospital. Med Forum Mon. 2015;26(7):10-3.

30. Maciejewska-Franczak M, Majak P, Kaczmarek J, et al. Satisfaction with treatment of atopic dermatitis in children. Dermatol Rev. 2016;2(2):109-18.

31. Scaria S, James E, Dharmaratnam AD. Epidemiology and treatment pattern of atopic dermatitis in patients attending a tertiary care teaching hospital. Int J Res Pharm Sci. 2011;2(1):38-44.

32. Kapoor R, Hoffstad O, Bilker W, et al. The frequency and intensity of topical pimecrolimus treatment in children with physician-confirmed mild to moderate atopic dermatitis. Pediatr Dermatol. 2009;26(6):682-7.

33. Martorell Aragones A, Felix Toledo R, Martorell Calatayud A, et al. Epidemiologic, clinical and socioeconomic factors of atopic dermatitis in Spain: Alergologica-2005. J Investig Allergol Clin Immunol. 2009;19(Suppl 2):27-33.

34. Alexander T, Maxim E, Cardwell LA, et al. Prescriptions for atopic dermatitis: oral corticosteroids remain commonplace. J Investig Dermatol. 2017;137(5):S121.

35. Schmitt J, Schmitt NM, Kirch W, et al. Outpatient care and medical treatment of children and adults with atopic eczema. J Dtsch Dermatol Ges. 2009;7(4):345-51.

36. Manthripragada AD, Pinheiro SP, MaCurdy TE, et al. Off-label topical calcineurin inhibitor use in children. Pediatrics. 2013;132(5):e1327-32.

37. Misery L, Ansolabehere X, Grandfils N, et al. Nineyear follow-up of children with atopic dermatitis by general practitioners. Dermatology. 2014;228(4):344-9.

38. Lopes T, Bordalo D, Madureira C, et al. Atopic dermatitis and allergic diseases: the role of allergic immunotherapy in a subgroup of patients. Allergy. 2016;71(Suppl 102):573.

39. Dabade TS, Davis DM, Wetter DA, et al. Wet dressing therapy in conjunction with topical corticosteroids is effective for rapid control of severe pediatric atopic dermatitis: experience with 218 patients over 30 years at Mayo Clinic. J Am Acad Dermatol. 2012;67(1):100-6.

40. Asch S, Joseph J, Major B, et al. Comparison of bleach, acetic acid, and other topical anti-infective treatments in pediatric atopic dermatitis: a retrospective cohort study on superinfection. J Am Acad Dermatol. 2017;76(6 Suppl 1):AB79.

41. Dilnawaz M, Sheikh ZI. Clinical audit of National Institute of Clinical Excellence (NICE) technology appraisal guidance (TAG) 81 and 82/clinical guidelines (CG57) on atopic eczema in children. J Pak Assoc Dermatol. 2013;23(1):47-51.

42. Morais-Almeida M, Cabral AJ. Off-label prescribing for allergic diseases in pre-school children. Allergol Immunopathol (Madr). 2014;42(4):342-7.

43. Horii KA, Simon SD, Liu DY, et al. Atopic dermatitis in children in the United States, 1997-2004: visit trends, patient and provider characteristics, and prescribing patterns. Pediatrics. 2007;120(3):e527-34.

44. Chawla V, Hogan MB, Moonie S, et al. Parental perception of efficacy of antihistamines for pruritus in pediatric atopic dermatitis. Allergy Asthma Proc. 2016;37(2):157-63.

45. Zuberbier T, Orlow SJ, Paller AS, et al. Patient perspectives on the management of atopic dermatitis. J Allergy Clin Immunol. 2006;118(1):226-32.

46. Abramovits W, Oquendo M. Hydrocortisone butyrate $0.1 \%$ cream (proprietary lipid rich cream vehicle) does not significantly suppress hypothalamic-pituitary-adrenal axis and is effective in pediatric patients 3 months and older with extensive atopic dermatitis. Skinmed. 2010;8(3):150-4.

47. Abramovits W, Oquendo M. Hydrocortisone butyrate $0.1 \%$ lipocream in pediatric patients with atopic dermatitis. Skinmed. 2010;8(2):72-9.

48. Breneman D, Fleischer AB Jr, Kaplan D, et al. Clobetasol propionate $0.05 \%$ lotion in the treatment of moderate to severe atopic dermatitis: a randomized evaluation versus clobetasol propionate emollient cream. J Drugs Dermatol. 2005;4(3):330-6.

49. Brown KL, Krejci-Manwaring J, Tusa MG, et al. Poor compliance with topical corticosteroids for atopic dermatitis despite severe disease. Dermatol Online J. 2008;14(9):13.

50. Conde JF, Kaur M, Fleischer AB Jr, et al. Adherence to clocortolone pivalate cream $0.1 \%$ in a pediatric population with atopic dermatitis. Cutis. 2008;81(5):435-41. 
51. Dohil MA, Alvarez-Connelly E, Eichenfield LF. Fluocinolone acetonide $0.01 \%$ in peanut oil: safety and efficacy data in the treatment of childhood atopic dermatitis in infants as young as 3 months of age. Pediatr Dermatol. 2009;26(3):262-8.

52. Eichenfield LF, Miller BH, Cutivate Lotion Study Group. Two randomized, double-blind, placebocontrolled studies of fluticasone propionate lotion $0.05 \%$ for the treatment of atopic dermatitis in subjects from 3 months of age. J Am Acad Dermatol. 2006;54(4):715-7.

53. Fukuie T, Hirakawa S, Narita $M$, et al. Potential preventive effects of proactive therapy on sensitization in moderate to severe childhood atopic dermatitis: a randomized, investigator-blinded, controlled study. J Dermatol. 2016;43(11):1283-92.

54. Glazenburg EJ, Wolkerstorfer A, Gerretsen AL, et al. Efficacy and safety of fluticasone propionate $0.005 \%$ ointment in the long-term maintenance treatment of children with atopic dermatitis: differences between boys and girls? Pediatr Allergy Immunol. 2009;20(1):59-66.

55. Hebert AA, Desonide Foam Phase III Clinical Study Group. Desonide foam 0.05\%: safety in children as young as 3 months. J Am Acad Dermatol. 2008;59(2):334-40.

56. Hebert AA, Cook-Bolden FE, Basu S, Desonide Hydrogel Study Group, et al. Safety and efficacy of desonide hydrogel $0.05 \%$ in pediatric subjects with atopic dermatitis. J Drugs Dermatol. 2007;6(2):175-81.

57. Hebert AA, Friedlander SF, Allen DB. Topical fluticasone propionate lotion does not cause HPA axis suppression. J Pediatr. 2006;149(3):378-82.

58. Hix E, Gustafson CJ, O’Neill JL, et al. Adherence to a five day treatment course of topical fluocinonide $0.1 \%$ cream in atopic dermatitis. Dermatol Online J. 2013;19(10):20029.

59. Katoh N, Hosoi H, Sugimoto T, et al. Features and prognoses of infantile patients with atopic dermatitis hospitalized for severe complications. J Dermatol. 2006;33(12):827-32.

60. Kerney DL, Ford RO, Gotz V. Self-reported participant experience with desonide hydrogel in the treatment of mild to moderate atopic dermatitis. Cutis. 2011;88(1 Suppl):18-24.

61. Khamaganova I. Alleviation of a severe pruritic flare-up in a 13-year-old child with chronic atopic dermatitis treated with methylprednisolone aceponate $0.1 \%$. J Eur Acad Dermatol Venereol. 2012;26(Suppl 6):20-1.
62. Kohn LL, Kang Y, Antaya RJ. A randomized, controlled trial comparing topical steroid application to wet versus dry skin in children with atopic dermatitis (AD). J Am Acad Dermatol. 2016;75(2):306-11.

63. Machado S. Effective use of methylprednisolone aceponate $0.1 \%$ in a 9-month-old infant with atopic eczema and sleep disturbance. J Eur Acad Dermatol Venereol. 2012;26(Suppl 6):14-5.

64. Ng SY, Begum S, Chong SY. Does order of application of emollient and topical corticosteroids make a difference in the severity of atopic eczema in children? Pediatr Dermatol. 2016;33(2):160-4.

65. Nutan FN, Kanwar AJ, Parsad D. The effect of topically applied corticosteroids on interleukin 1beta levels in patients with atopic dermatitis. J Eur Acad Dermatol Venereol. 2012;26(8):1020-2.

66. Pellanda C, Weber M, Bircher A, et al. Low-dose triamcinolone acetonide in the phytocosmetic lichtena reduces inflammation in mild to moderate atopic dermatitis. Dermatology. $2005 ; 211(4): 338-40$.

67. Sandoval LF, Huang K, O'Neill JL, et al. Measure of atopic dermatitis disease severity using actigraphy. J Cutan Med Surg. 2014;18(1):49-55.

68. Schlessinger J, Miller B, Gilbert RD, Vanos Study Group, et al. An open-label adrenal suppression study of $0.1 \%$ fluocinonide cream in pediatric patients with atopic dermatitis. Arch Dermatol. 2006;142(12):1568-72.

69. Torrelo A. Methylprednisolone aceponate $0.1 \%$ in the treatment of pruritic lichenified eczema in a 3 -year-old child with chronic atopic dermatitis. J Eur Acad Dermatol Venereol. 2012;26(Suppl 6):18-9.

70. Woods MT, Brown PA, Baig-Lewis SF, et al. Effects of a novel formulation of fluocinonide $0.1 \%$ cream on skin barrier function in atopic dermatitis. J Drugs Dermatol. 2011;10(2):171-6.

71. Yentzer BA, Ade RA, Fountain JM, et al. Improvement in treatment adherence with a 3-day course of fluocinonide cream $0.1 \%$ for atopic dermatitis. Cutis. 2010;86(4):208-13.

72. Yentzer BA, Camacho FT, Young T, et al. Good adherence and early efficacy using desonide hydrogel for atopic dermatitis: results from a program addressing patient compliance. J Drugs Dermatol. 2010;9(4):324-9.

73. Arkwright PD, Gillespie MC, Ewing CI, et al. Blinded side-to-side comparison of topical corticosteroid and tacrolimus ointment in children with moderate 
to severe atopic dermatitis. Clin Exp Dermatol. 2007;32(2):145-7.

74. Aschoff R, Schmitt J, Knuschke P, et al. Evaluation of the atrophogenic potential of hydrocortisone $1 \%$ cream and pimecrolimus $1 \%$ cream in uninvolved forehead skin of patients with atopic dermatitis using optical coherence tomography. Exp Dermatol. 2011;20(10):832-6.

75. Bieber T, Vick K, Folster-Holst R, et al. Efficacy and safety of methylprednisolone aceponate ointment $0.1 \%$ compared to tacrolimus $0.03 \%$ in children and adolescents with an acute flare of severe atopic dermatitis. Allergy. 2007;62(2):184-9.

76. Boguniewicz M, Abramovits W, Paller A, et al. A multiple-domain framework of clinical, economic, and patient-reported outcomes for evaluating benefits of intervention in atopic dermatitis. J Drugs Dermatol. 2007;6(4):416-23.

77. Breneman D, Fleischer AB Jr, Abramovits W, et al. Tacrolimus Ointment Study Group. Intermittent therapy for flare prevention and long-term disease control in stabilized atopic dermatitis: a randomized comparison of 3-times-weekly applications of tacrolimus ointment versus vehicle. J Am Acad Dermatol. 2008;58(6):990-9.

78. Chapman MS, Schachner LA, Breneman D, US Tacrolimus Ointment Study Group, et al. Tacrolimus ointment $0.03 \%$ shows efficacy and safety in pediatric and adult patients with mild to moderate atopic dermatitis. J Am Acad Dermatol. 2005;53(2 Suppl 2):S177-85.

79. De Backer M, Morren MA, Boonen H, et al. Belgian observational drug utilization study of pimecrolimus cream $1 \%$ in routine daily practice in atopic dermatitis. Dermatology. 2008;217(2):156-63.

80. Doss N, Kamoun MR, Dubertret L, et al. Efficacy of tacrolimus $0.03 \%$ ointment as second-line treatment for children with moderate-to-severe atopic dermatitis: evidence from a randomized, doubleblind non-inferiority trial vs. fluticasone $0.005 \%$ ointment. Pediatr Allergy Immunol. 2010;21(2 Pt 1):321-9.

81. Eichenfield LF, Ho V, Matsunaga J, et al. Blood concentrations, tolerability and efficacy of pimecrolimus cream 1\% in Japanese infants and children with atopic dermatitis. J Dermatol. 2007;34(4):231-6.

82. Eichenfield LF, Lucky AW, Langley RG, et al. Use of pimecrolimus cream 1\% (Elidel) in the treatment of atopic dermatitis in infants and children: the effects of ethnic origin and baseline disease severity on treatment outcome. Int J Dermatol. 2005;44(1):70-5.

83. Ellis CN, Kahler KH, Grueger J, et al. Cost effectiveness of management of mild-to-moderate atopic dermatitis with $1 \%$ pimecrolimus cream in children and adolescents 2-17 years of age. Am J Clin Dermatol. 2006;7(2):133-9.

84. Emer JJ, Frankel A, Sohn A, et al. A bilateral comparison study of pimecrolimus cream $1 \%$ and a topical medical device cream in the treatment of patients with atopic dermatitis. J Drugs Dermatol. 2011;10(7):735-43.

85. Fowler J, Johnson A, Chen M, et al. Improvement in pruritus in children with atopic dermatitis using pimecrolimus cream 1\%. Cutis. 2007;79(1):65-72.

86. Hanifin JM, Paller AS, Eichenfield L, US Tacrolimus Ointment Study Group, et al. Efficacy and safety of tacrolimus ointment treatment for up to 4 years in patients with atopic dermatitis. J Am Acad Dermatol. 2005;53(2 Suppl 2):S186-94.

87. Hoeger PH, Lee KH, Jautova J, et al. The treatment of facial atopic dermatitis in children who are intolerant of, or dependent on, topical corticosteroids: a randomized, controlled clinical trial. Br J Dermatol. 2009;160(2):415-22.

88. Hon KL, Lam MC, Leung TF, et al. Assessing itch in children with atopic dermatitis treated with tacrolimus: objective versus subjective assessment. Adv Ther. 2007;24(1):23-8.

89. Jirakova A, Rob F, Secnikova Z, et al. Topical corticosteroids but not calcineurin inhibitors induced atrophy after four weeks. J Biol Regul Homeost Agents. 2015;29(3):701-6.

90. Khan AM, Khondker L, Afroze D. Comparative efficacy of topical mometasone furoate $0.1 \%$ cream vs topical tacrolimus $0.03 \%$ ointment in the treatment of atopic dermatitis. J Pak Assoc Dermatol. 2014;24(1):57-62.

91. Kim HO, Lee $\mathrm{CH}$, Ahn $\mathrm{HK}$, et al. Effects of tacrolimus ointment on the expression of substance $P$, nerve growth factor, and neurotrophin-3 in atopic dermatitis. Int J Dermatol. 2009;48(4):431-8.

92. Kirsner RS, Heffernan MP, Antaya R. Safety and efficacy of tacrolimus ointment versus pimecrolimus cream in the treatment of patients with atopic dermatitis previously treated with corticosteroids. Acta Derm Venereol. 2010;90(1):58-64.

93. Kitchin O, Masekela R, Moodley T, et al. The value of pimecrolimus in improving quality of life of children with severe eczema-an open non-randomised study. S Afr Fam Pract. 2010;52(1):69-71. 
94. Kondo Y, Nakajima Y, Komatsubara R, et al. Shortterm efficacy of tacrolimus ointment and impact on quality of life. Pediatr Int. 2009;51(3):385-9.

95. Koo JY, Fleischer $\mathrm{AB} J \mathrm{~J}$, Abramovits $\mathrm{W}$, et al. Tacrolimus ointment is safe and effective in the treatment of atopic dermatitis: results in 8000 patients. J Am Acad Dermatol. 2005;53(2 Suppl 2):S195-205.

96. Langley RG, Eichenfield LF, Lucky AW, et al. Sustained efficacy and safety of pimecrolimus cream $1 \%$ when used long-term (up to 26 weeks) to treat children with atopic dermatitis. Pediatr Dermatol. 2008;25(3):301-7.

97. Lee SJ, Woo SI, Ahn SH, et al. Functional interpretation of metabolomics data as a new method for predicting long-term side effects: treatment of atopic dermatitis in infants. Sci Rep. 2014;4:7408.

98. Leung DY, Hanifin JM, Pariser DM, et al. Effects of pimecrolimus cream $1 \%$ in the treatment of patients with atopic dermatitis who demonstrate a clinical insensitivity to topical corticosteroids: a randomized, multicentre vehicle-controlled trial. $\mathrm{Br}$ J Dermatol. 2009;161(2):435-43.

99. Ling M, Gottlieb A, Pariser D, et al. A randomized study of the safety, absorption and efficacy of pimecrolimus cream 1\% applied twice or four times daily in patients with atopic dermatitis. J Dermatol Treat. 2005;16(3):142-8.

100. Lubbe J, Friedlander SF, Cribier B, NOBEL (New Online Based ELidel) Study Group, et al. Safety, efficacy, and dosage of $1 \%$ pimecrolimus cream for the treatment of atopic dermatitis in daily practice. Am J Clin Dermatol. 2006;7(2):121-31.

101. Mandelin JM, Rubins A, Remitz A, et al. Long-term efficacy and tolerability of tacrolimus $0.03 \%$ ointment in infants: a two-year open-label study. Int J Dermatol. 2012;51(1):104-10.

102. McKenna SP, Whalley D, de Prost Y, et al. Treatment of paediatric atopic dermatitis with pimecrolimus (Elidel, SDZ ASM 981): impact on quality of life and health-related quality of life. J Eur Acad Dermatol Venereol. 2006;20(3):248-54.

103. Neumann E, Amtage D, Bruckner-Tuderman L, et al. A single-center open-label long-term comparison of tacrolimus ointment and topical corticosteroids for treatment of atopic dermatitis. J Dtsch Dermatol Ges. 2008;6(7):548-53.

104. Paller AS, Eichenfield LF, Kirsner RS, US Tacrolimus Ointment Study Group, et al. Three times weekly tacrolimus ointment reduces relapse in stabilized atopic dermatitis: a new paradigm for use. Pediatrics. 2008;122(6):e1210-8.
105. Paller AS, Lebwohl M, Fleischer AB Jr, US/Canada Tacrolimus Ointment Study Group, et al. Tacrolimus ointment is more effective than pimecrolimus cream with a similar safety profile in the treatment of atopic dermatitis: results from 3 randomized, comparative studies. J Am Acad Dermatol. 2005;52(5):810-22.

106. Papp KA, Breuer K, Meurer M, et al. Long-term treatment of atopic dermatitis with pimecrolimus cream $1 \%$ in infants does not interfere with the development of protective antibodies after vaccination. J Am Acad Dermatol. 2005;52(2):247-53.

107. Papp KA, Werfel T, Folster-Holst R, et al. Long-term control of atopic dermatitis with pimecrolimus cream $1 \%$ in infants and young children: a two-year study. J Am Acad Dermatol. 2005;52(2):240-6.

108. Park CW, Lee BH, Han HJ, et al. Tacrolimus decreases the expression of eotaxin, CCR3, RANTES and interleukin-5 in atopic dermatitis. Br J Dermatol. $2005 ; 152(6): 1173-81$.

109. Park CW, Lee $\mathrm{BH}$, Lee $\mathrm{CH}$. Tacrolimus reduces staphylococcal colonization on the skin in Korean atopic dermatitis patients. Drugs Exp Clin Res. $2005 ; 31(2): 77-87$.

110. Rahman MF, Nandi AK, Kabir S, et al. Topical tacrolimus versus hydrocortisone on atopic dermatitis in paediatric patients: a randomized controlled trial. Mymensingh Med J. 2015;24(3):457-63.

111. Rahman MF, Rashid MM, Sikder AU, et al. Efficacy of topical tacrolimus in atopic dermatitis. J Pak Assoc Dermatol. 2008;18(2):84-92.

112. Reitamo S, Allsopp R. Treatment with twice-weekly tacrolimus ointment in patients with moderate to severe atopic dermatitis: results from two randomized, multicentre, comparative studies. J Dermatol Treat. 2010;21(1):34-44.

113. Reitamo S, Rustin M, Harper J, 0.1\% Tacrolimus Ointment Long-term Follow-up Study Group, et al. A 4-year follow-up study of atopic dermatitis therapy with $0.1 \%$ tacrolimus ointment in children and adult patients. Br J Dermatol. 2008;159(4):942-51.

114. Remitz A, Harper J, Rustin M, European Tacrolimus Ointment Study Group, et al. Long-term safety and efficacy of tacrolimus ointment for the treatment of atopic dermatitis in children. Acta Derm Venereol. 2007;87(1):54-61.

115. Ring J, Abraham A, de Cuyper C, et al. Control of atopic eczema with pimecrolimus cream $1 \%$ under daily practice conditions: results of a $>2000$ patient study. J Eur Acad Dermatol Venereol. 2008;22(2): 195-203. 
116. Schachner LA, Lamerson C, Sheehan MP, US Tacrolimus Ointment Study Group, et al. Tacrolimus ointment $0.03 \%$ is safe and effective for the treatment of mild to moderate atopic dermatitis in pediatric patients: results from a randomized, double-blind, vehicle-controlled study. Pediatrics. 2005;116(3):e334-42.

117. Schneider L, Hanifin J, Boguniewicz M, et al. Study of the atopic March: development of atopic comorbidities. Pediatr Dermatol. 2016;33(4): 388-98.

118. Siegfried E, Korman N, Molina C, et al. Safety and efficacy of early intervention with pimecrolimus cream 1\% combined with corticosteroids for major flares in infants and children with atopic dermatitis. J Dermatol Treat. 2006;17(3):143-50.

119. Sigurgeirsson B, Boznanski A, Todd G, et al. Safety and efficacy of pimecrolimus in atopic dermatitis: a 5-year randomized trial. Pediatrics. 2015;135(4): 597-606.

120. Sigurgeirsson B, Ho V, Ferrandiz C, Pimecrolimus $1 \%$ cream in (paediatric) eczema: prevention of progression multi-centre investigator study group, et al. Effectiveness and safety of a prevention-offlare-progression strategy with pimecrolimus cream $1 \%$ in the management of paediatric atopic dermatitis. J Eur Acad Dermatol Venereol. 2008;22(11):1290-301.

121. Simon D, Lubbe J, Wuthrich B, et al. Benefits from the use of a pimecrolimus-based treatment in the management of atopic dermatitis in clinical practice. Analysis of a Swiss cohort. Dermatology. 2006;213(4):313-8.

122. Singalavanija S, Noppakun N, Limpongsanuruk W, et al. Efficacy and safety of tacrolimus ointment in pediatric patients with moderate to severe atopic dermatitis. J Med Assoc Thai. 2006;89(11):1915-22.

123. Spergel JM, Boguniewicz M, Schneider L, et al. Food allergy in infants with atopic dermatitis: limitations of food-specific IgE measurements. Pediatrics. 2015;136(6):e1530-8.

124. Staab D, Kaufmann R, Brautigam M, CASM981CDE04-Study Group, et al. Treatment of infants with atopic eczema with pimecrolimus cream $1 \%$ improves parents' quality of life: a multicenter, randomized trial. Pediatr Allergy Immunol. 2005;16(6):527-33.

125. Stiehm ER, Roberts RL, Kaplan MS, et al. Pneumococcal seroconversion after vaccination for children with atopic dermatitis treated with tacrolimus ointment. J Am Acad Dermatol. 2005;53(2 Suppl 2):S206-13.
126. Thaci D, Chambers C, Sidhu M, et al. Twice-weekly treatment with tacrolimus $0.03 \%$ ointment in children with atopic dermatitis: clinical efficacy and economic impact over 12 months. J Eur Acad Dermatol Venereol. 2010;24(9):1040-6.

127. Thaci D, Reitamo S, Gonzalez Ensenat MA, European Tacrolimus Ointment Study Group, et al. Proactive disease management with $0.03 \%$ tacrolimus ointment for children with atopic dermatitis: results of a randomized, multicentre, comparative study. Br J Dermatol. 2008;159(6):1348-56.

128. Thompson MM, Hanifin JM. Effective therapy of childhood atopic dermatitis allays food allergy concerns. J Am Acad Dermatol. 2005;53(2 Suppl 2):S214-9.

129. Yeung CK, Ma KC, Chan HH. Efficacy and safety of tacrolimus ointment monotherapy in chinese children with atopic dermatitis. Skinmed. 2006;5(1):12-7.

130. Zuberbier T, Brautigam M. Long-term management of facial atopic eczema with pimecrolimus cream $1 \%$ in paediatric patients with mild to moderate disease. J Eur Acad Dermatol Venereol. 2008;22(6):718-21.

131. Zuberbier T, Heinzerling L, Bieber T, et al. Steroidsparing effect of pimecrolimus cream 1\% in children with severe atopic dermatitis. Dermatology. 2007;215(4):325-30.

132. Boguniewicz M, Paller AS, Tom WL, et al. Efficacy and safety of crisaborole topical ointment, $2 \%$, a novel, nonsteroidal, topical, anti-inflammatory, phosphodiesterase inhibitor in 2 phase 3 studies in children and adults with mild-to-moderate atopic dermatitis. J Allergy Clin Immunol. 2016;137(2 Suppl 1):AB397.

133. Draelos ZD, Stein Gold L, Murrell D, et al. Post-hoc analyses of the effect of AN2728 topical ointment, $2 \%$ on atopic dermatitis-associated pruritus. Presented at 24th annual congress of the European Academy of Dermatology and Venereology; 2015; Copenhagen, EADV 2015.

134. Eichenfield L, Call R, Forsha D, et al. Long-term safety of crisaborole in children and adults with mild-to-moderate atopic dermatitis. Pediatr Dermatol. 2016;33(Suppl 1):S46-7.

135. Fowler J, Cook-Bolden F, Pariser D, et al. Crisaborole ointment improves global atopic dermatitis severity: pooled results from two phase 3 clinical trials. J Am Acad Dermatol. 2017;76(6 Suppl 1):AB86.

136. Guttman-Yassky E, Hanifin J, Murell D, et al. Crisaborole ointment provides early relief of pruritus regardless of baseline disease severity in two phase 3 
clinical trials in patients with mild or moderate AD. J Am Acad Dermatol. 2017;76(6 Suppl 1):AB86.

137. Hanifin JM, Ellis CN, Frieden IJ, et al. OPA-15406, a novel, topical, nonsteroidal, selective phosphodiesterase-4 (PDE4) inhibitor, in the treatment of adult and adolescent patients with mild to moderate atopic dermatitis (AD): a phase-II randomized, double-blind, placebo-controlled study. J Am Acad Dermatol. 2016;75(2):297-305.

138. Hebert AA, Eichenfield L, Lebwohl MG, Elsevier, et al. Reduced pruritus and signs of atopic dermatitis in phase 3 trials with a nonsteroidal topical phosphodiesterase inhibitor, crisaborole. J Investig Dermatol. 2016;136(5):S49.

139. Murrell D, Spelman L, Tom W, et al. AN2728 topical ointment, $2 \%$ in the treatment of children, adolescents, and adults with atopic dermatitis: summary of the phase $1 b / 2$ studies. Presented at 24 th annual congress of the European Academy of Dermatology and Venereology; 2015; Copenhagen, EADV 2015.

140. Nemoto O, Hayashi N, Kitahara Y, Japanese E6005 Study Investigators, et al. Effect of topical phosphodiesterase 4 inhibitor E6005 on Japanese children with atopic dermatitis: results from a randomized, vehicle-controlled exploratory trial. J Dermatol. 2016;43(8):881-7.

141. Paller A, Tom W, Lebwohl M, et al. Two phase 3 studies in atopic dermatitis with crisaborole, the novel, nonsteroidal topical phosphodiesterase 4 inhibitor. Pediatr Dermatol. 2016;33(Suppl 1):S19.

142. Paller A, Tom W, Lebwohl MM, et al. Crisaborole topical ointment, 2\%: A novel, nonsteroidal, topical antiinflammatory, phosphodiesterase 4 inhibitor: results from two phase 3 studies treating children and adult patients with mild to moderate atopic dermatitis. J Am Acad Dermatol. 2016;74(5 Suppl 1):AB86.

143. Paller AS, Tom WL, Call RS, et al. Phase 3 studies in atopic dermatitis with the novel, nonsteroidal topical phosphodiesterase 4 inhibitor, crisaborole. J Investig Dermatol. 2016;136(5):S50.

144. Simpson E, Paller A, Boguniewicz M, et al. Crisaborole demonstrates improvement in quality of life in patients with mild to moderate atopic dermatitis. Ann Allergy Asthma Immunol. 2016;117(5):S20-1.

145. Simpson E, Paller A, Boguniewicz M, et al. Crisaborole topical ointment, 2\%, demonstrates improvement in the quality of life of patients with mild to moderate atopic dermatitis. Presented at 25th annual congress of the European Academy of Dermatology and Venereology; 2016; Vienna, EADV 2016.
146. Stein Gold LF, Spelman L, Spellman MC, et al. A phase 2, randomized, controlled, dose-ranging study evaluating crisaborole topical ointment, $0.5 \%$ and $2 \%$ in adolescents with mild to moderate atopic dermatitis. J Drugs Dermatol. 2015;14(12):1394-9.

147. Zane LT, Kircik L, Call R, et al. Crisaborole topical ointment, $2 \%$ in patients ages 2 to 17 years with atopic dermatitis: a phase $1 \mathrm{~b}$, open-label, maximaluse systemic exposure study. Pediatr Dermatol. 2016;33(4):380-7.

148. Canpolat F, Erkocoglu M, Tezer H, et al. Hydrocortisone acetate alone or combined with mupirocin for atopic dermatitis in infants under two years of age- - a randomized double blind pilot trial. Eur Rev Med Pharmacol Sci. 2012;16(14):1989-93.

149. Gong JQ, Lin L, Lin T, et al. Skin colonization by Staphylococcus aureus in patients with eczema and atopic dermatitis and relevant combined topical therapy: a double-blind multicentre randomized controlled trial. Br J Dermatol. 2006;155(4):680-7.

150. Hebert AA, Koo J, Fowler J, et al. Desoximetasone $0.25 \%$ and tacrolimus $0.1 \%$ ointments versus tacrolimus alone in the treatment of atopic dermatitis. Cutis. 2006;78(5):357-63.

151. Hon KL, Wang SS, Lee KK, et al. Combined antibiotic/corticosteroid cream in the empirical treatment of moderate to severe eczema: friend or foe? J Drugs Dermatol. 2012;11(7):861-4.

152. Hung SH, Lin YT, Chu CY, et al. Staphylococcus colonization in atopic dermatitis treated with fluticasone or tacrolimus with or without antibiotics. Ann Allergy Asthma Immunol. 2007;98(1):51-6.

153. Janmohamed SR, Oranje AP, Devillers AC, et al. The proactive wet-wrap method with diluted corticosteroids versus emollients in children with atopic dermatitis: a prospective, randomized, doubleblind, placebo-controlled trial. J Am Acad Dermatol. 2014;70(6):1076-82.

154. Kubota Y, Yoneda K, Nakai K, et al. Effect of sequential applications of topical tacrolimus and topical corticosteroids in the treatment of pediatric atopic dermatitis: an open-label pilot study. J Am Acad Dermatol. 2009;60(2):212-7.

155. Leloup P, Stalder JF, Barbarot S. Outpatient home-based wet wrap dressings with topical steroids with children with severe recalcitrant atopic dermatitis: a feasibility pilot study. Pediatr Dermatol. 2015;32(4):e177-8.

156. Meurer M, Eichenfield LF, Ho V, et al. Addition of pimecrolimus cream $1 \%$ to a topical corticosteroid treatment regimen in paediatric patients with severe atopic dermatitis: a randomized, double-blind trial. J Dermatol Treat. 2010;21(3):157-66. 
157. Msika P, De Belilovsky C, Piccardi N, et al. New emollient with topical corticosteroid-sparing effect in treatment of childhood atopic dermatitis: SCORAD and quality of life improvement. Pediatr Dermatol. 2008;25(6):606-12.

158. O'Keeffe C, Cox H, Leitao E, et al. Atopic eczemacan a multidisciplinary and multisystem approach avoid the need for systemic immunosuppression? Allergy. 2014;69(Suppl 99):584.

159. Sikder AU, Al Mamun S, Khan RM, et al. Topical $0.03 \%$ tacrolimus ointment, $0.05 \%$ clobetasone butyrate cream alone and their combination in older children with atopic dermatitis-an open randomized comparative study. J Pak Assoc Dermatol. 2005;15(4):304-12.

160. Simpson E, Dutronc Y. A new body moisturizer increases skin hydration and improves atopic dermatitis symptoms among children and adults. J Drugs Dermatol. 2011;10(7):744-9.

161. Spergel JM, Boguniewicz M, Paller AS, et al. Addition of topical pimecrolimus to once-daily mid-potent steroid confers no short-term therapeutic benefit in the treatment of severe atopic dermatitis; a randomized controlled trial. $\mathrm{Br} \mathrm{J}$ Dermatol. 2007;157(2):378-81.

162. Szczepanowska J, Reich A, Szepietowski JC. Emollients improve treatment results with topical corticosteroids in childhood atopic dermatitis: a randomized comparative study. Pediatr Allergy Immunol. 2008;19(7):614-8.

163. Tzung TY, Lin CB, Chen YH, et al. Pimecrolimus and narrowband UVB as monotherapy or combination therapy in children and adolescents with atopic dermatitis. Acta Derm Venereol. 2006;86(1):34-8.

164. Tan WP, Suresh S, Tey HL, et al. A randomized double-blind controlled trial to compare a triclosancontaining emollient with vehicle for the treatment of atopic dermatitis. Clin Exp Dermatol. 2010;35(4):e109-12.

165. Horiuchi Y. Topical streptococcal preparation, OK432, for atopic dermatitis. J Dermatol Treat. 2005;16(2):117-20.

166. Hon KL, Ching GK, Leung TF, et al. Efficacy and tolerability at 3 and 6 months following use of azathioprine for recalcitrant atopic dermatitis in children and young adults. J Dermatol Treat. 2009;20(3):141-5.

167. Waxweiler WT, Agans R, Morrell DS. Systemic treatment of pediatric atopic dermatitis with azathioprine and mycophenolate mofetil. Pediatr Dermatol. 2011;28(6):689-94.
168. Garrido Colmenero C, Blasco Morente G, Tercedor Sanchez J. Oral cyclosporine weekend therapy: a new maintenance therapeutic option in patients with severe atopic dermatitis. Pediatr Dermatol. 2015;32(4):551-2.

169. Caufield M, Tom WL. Oral azathioprine for recalcitrant pediatric atopic dermatitis: clinical response and thiopurine monitoring. J Am Acad Dermatol. 2013;68(1):29-35.

170. El-Khalawany MA, Hassan H, Shaaban D, et al. Methotrexate versus cyclosporine in the treatment of severe atopic dermatitis in children: a multicenter experience from Egypt. Eur J Pediatr. 2013;172(3):351-6.

171. Kwon HB, Ahn BJ, Choi Y, et al. Combination of glucosamine improved therapeutic effect of lowdose cyclosporin $\mathrm{A}$ in patients with atopic dermatitis: a pilot study. J Dermatol. 2013;40(3): 207-10.

172. Jin SY, Lim WS, Sung NH, et al. Combination of glucosamine and low-dose cyclosporine for atopic dermatitis treatment: a randomized, placebo-controlled, double-blind, parallel clinical trial. Dermatol Ther. 2015;28(1):44-51.

173. Meggitt SJ, Gray JC, Reynolds NJ. Azathioprine dosed by thiopurine methyltransferase activity for moderate-to-severe atopic eczema: a double-blind, randomised controlled trial. Lancet. 2006;367(9513):839-46.

174. Adil H, Siegfried E, Armbrecht E. Systemic treatment for severe pediatric atopic dermatitis. J Am Acad Dermatol. 2015;72(5 Suppl 1):AB76.

175. Deo M, Yung A, Hill S, et al. Methotrexate for treatment of atopic dermatitis in children and adolescents. Int J Dermatol. 2014;53(8):1037-41.

176. Heller M, Shin HT, Orlow SJ, et al. Mycophenolate mofetil for severe childhood atopic dermatitis: experience in 14 patients. $\mathrm{Br} \mathrm{J}$ Dermatol. 2007;157(1):127-32.

177. Hernandez-Martin A, Noguera-Morel L, Torrelo A, et al. Cyclosporin therapy in children with severe atopic dermatitis. Efficacy and adverse effects profile assessment. Pediatr Dermatol. 2016;33(Suppl 1):S45.

178. Kudryavtseva A, Balabolkin I, Ksenzova L, et al. Cyclosporin A and resistant atopic dermatitis with children. Allergy. 2015;70(Suppl 101):534.

179. Almeida JP, Tapadinhas MC, Marques MS. Clinical efficacy of oral azathioprine for severe refractory pediatric atopic eczema. Allergy. 2014;69(Suppl 99):237-8. 
180. Beaumont DR, Arkwright PD. Factors determining the effectiveness of oral ciclosporin in the treatment of severe childhood atopic dermatitis. J Dermatol Treat. 2012;23(5):318-22.

181. Martinez-Tadeo JA, Hernandez-Santana G, Rodriguez-Plata E, et al. Case report: specific immunotherapy with dust mite allergens in a child with severe atopic dermatitis. Allergol Immunopathol (Madr). 2011;39(5):310-1.

182. Kwon YS, Oh SH, Wu WH, et al. CC chemokines as potential immunologic markers correlated with clinical improvement of atopic dermatitis patients by immunotherapy. Exp Dermatol. 2010;19(3): 246-51.

183. Nahm DH, Kim ME, Kwon B, et al. Clinical efficacy of subcutaneous allergen immunotherapy in patients with atopic dermatitis. Yonsei Med J. 2016;57(6):1420-6.

184. Nahm DH, Lee ES, Park HJ, et al. Treatment of atopic dermatitis with a combination of allergenspecific immunotherapy and a histamine-immunoglobulin complex. Int Arch Allergy Immunol. 2008;146(3):235-40.

185. Cadario G, Galluccio AG, Pezza M, et al. Sublingual immunotherapy efficacy in patients with atopic dermatitis and house dust mites sensitivity: a prospective pilot study. Curr Med Res Opin. 2007;23(10):2503-6.

186. Brunetti L, Francavilla R, Tesse R, et al. Effects of oral bacterial immunotherapy in children with atopic eczema/dermatitis syndrome: a pilot study. BioDrugs. 2005;19(6):393-9.

187. Morais-Almeida M, Arede C, Sampaio G, et al. Ultrarush schedule of subcutaneous immunotherapy with modified allergen extracts is safe in paediatric age. Asia Pac Allergy. 2016;6(1):35-42.

188. Czarnecka-Operacz M, Silny W. Specific immunotherapy in atopic dermatitis-Four-year treatment in different age and airborne allergy type subgroups. Acta Dermatovenerol Croat. 2006;14(4):230-40.

189. Zhong H, Deng X, Song Z, et al. Immunological changes after ASIT in AD allergen-specific immunotherapy and their potential correlation with clinical response in patients with atopic dermatitis patients sensitized to house dust mite. J Eur Acad Dermatol Venereol. 2015;29(7):1318-24.

190. Czarnecka-Operacz M, Silny W. Immunological parameters in the sera of patients with atopic dermatitis and airborne allergy treated with allergy vaccines. Acta Dermatovenerol Croat. 2006;14(1):8-20.
191. Marogna M, Braidi C, Colombo C, et al. Can sublingual allergen immunotherapy for house dust mites influence the long-term evolution of severe atopic dermatitis and the progression to respiratory allergy? Results of an observational comparison with pharmacotherapy. Allergy. 2015;70(Suppl 101):461.

192. Wyrzykowska N, Czarnecka-Operacz M, Adamski Z. Long-term efficacy of allergen specific immunotherapy in atopic dermatitis patients in relation to quality of life. Eur Ann Allergy Clin Immunol. 2015;47(1):5-9.

193. Berth-Jones J, Arkwright PD, Marasovic D, et al. Killed Mycobacterium vaccae suspension in children with moderate-to-severe atopic dermatitis: a randomized, double-blind, placebo-controlled trial. Clin Exp Allergy. 2006;36(9):1115-21.

194. Pajno GB, Caminiti L, Vita D, et al. Sublingual immunotherapy in mite-sensitized children with atopic dermatitis: a randomized, double-blind, placebo-controlled study. J Allergy Clin Immunol. 2007;120(1):164-70.

195. Davies MG, Symons C, Shaw S, et al. An open study to assess the efficacy clinically and immunologically of $M$. vaccae vaccine in patients with atopic dermatitis. J Dermatol Treat. 2006;17(2):74-7.

196. Sanchez J, Cardona R. Effect of immunotherapy on basophil activation induced by allergens in patients with atopic dermatitis. Rev Alerg Mex. 2014;61(3):168-77.

197. Di Rienzo V, Cadario G, Grieco T, et al. Sublingual immunotherapy in mite-sensitized children with atopic dermatitis: a randomized, open, parallelgroup study. Ann Allergy Asthma Immunol. 2014;113(6):671.e1-673.e1.

198. Cardona R, Lopez E, Beltran J, et al. Safety of immunotherapy in patients with rhinitis, asthma or atopic dermatitis using an ultra-rush buildup. A retrospective study. Allergol Immunopathol (Madr). 2014;42(2):90-5.

199. Slavyanskaya T, Derkach V. Targeted therapy in children with atopic dermatitis. J Allergy Clin Immunol. 2016;137(2 Suppl 1):AB148.

200. Caruso C, Gaeta F, Valluzzi RL, et al. Omalizumab efficacy in a girl with atopic eczema. Allergy. 2010;65(2):278-9.

201. Geraldo DJ, Mendes A, Pedro E, et al. Asthma and atopic eczema in a child: successful treatment with omalizumab. Rev Port Imunoalergol. 2013;21(1):49-53. 
202. Wlodek C, Hewitt H, Kennedy CT. Use of ustekinumab for severe refractory atopic dermatitis in a young teenager. Clin Exp Dermatol. 2016;41(6):625-7.

203. Amrol D. Anti-immunoglobulin E in the treatment of refractory atopic dermatitis. South Med J. 2010;103(6):554-8.

204. Eguíluz-Gracia I, Robledo-Echarren T, Suárez-Fernández $\mathrm{R}$, et al. Omalizumab for the treatment of atopic dermatitis. Clin Investig (Lond). 2015;5(2):121-36.

205. Lacombe Barrios J, Begin P, Paradis L, et al. Anti-IgE therapy and severe atopic dermatitis: a pediatric perspective. J Am Acad Dermatol. 2013;69(5):832-4.

206. Lane JE, Cheyney JM, Lane TN, et al. Treatment of recalcitrant atopic dermatitis with omalizumab. J Am Acad Dermatol. 2006;54(1):68-72.

207. Sheinkopf LE, Rafi AW, Do LT, et al. Efficacy of omalizumab in the treatment of atopic dermatitis: a pilot study. Allergy Asthma Proc. 2008;29(5):530-7.

208. Ramirez del Pozo ME, Contreras Contreras E, Lopez Tiro J, et al. Omalizumab (an anti-IgE antibody) in the treatment of severe atopic eczema. J Investig Allergol Clin Immunol. 2011;21(5):416-7.

209. Iyengar SR, Hoyte EG, Loza A, et al. Immunologic effects of omalizumab in children with severe refractory atopic dermatitis: a randomized, placebocontrolled clinical trial. Int Arch Allergy Immunol. 2013;162(1):89-93.

210. Nahm DH, Kim ME. Treatment of severe atopic dermatitis with a combination of subcutaneous allergen immunotherapy and cyclosporin. Yonsei Med J. 2012;53(1):158-63.

211. Slavyanskaya T, Derkach V. Targeted therapy as a basic issue of atopic dermatitis' management in patients. Allergy. 2016;71(Suppl 102):399.

212. Derkach V, Slavyanskaya T, Sangidorj B. Combination immunotropic therapy of atopic dermatitis in children: cost-benefit analysis. J Allergy Clin Immunol. 2015;135(2 Suppl 1):AB265.

213. Slavyanskaya T, Derkach V. Rationale for the use of multiagent immunotherapy in children with atopic dermatitis. Allergy. 2014;69(Suppl 99):190.

214. Saporito RC, Cohen DJ. Apremilast use for moderate-to-severe atopic dermatitis in pediatric patients. Case Rep Dermatol. 2016;8(2):179-84.

215. Van Onselen J. Itching to get over it. J Fam Health Care. 2011;21(3):12-4, 16.
216. Puviani M, Agostinis F, Milani M. Barrier repair therapy for facial atopic eczema with a non-steroidal emollient cream containing rhamnosoft, ceramides and iso-leucine. A six-case report series. Minerva Pediatr. 2014;66(4):307-11.

217. Flores GE, Seite S, Henley JB, et al. Microbiome of affected and unaffected skin of patients with atopic dermatitis before and after emollient treatment. J Drugs Dermatol. 2014;13(11):1365-72.

218. Gelmetti C, Boralevi F, Seite S, et al. Quality of life of parents living with a child suffering from atopic dermatitis before and after a 3-month treatment with an emollient. Pediatr Dermatol. 2012;29(6):714-8.

219. Hon KL, Pong NH, Wang SS, et al. Acceptability and efficacy of an emollient containing ceramide-precursor lipids and moisturizing factors for atopic dermatitis in pediatric patients. Drugs $\mathrm{R} D$. 2013;13(1):37-42.

220. Hon KL, Tsang YC, Pong NH, et al. Patient acceptability, efficacy, and skin biophysiology of a cream and cleanser containing lipid complex with shea butter extract versus a ceramide product for eczema. Hong Kong Med J. 2015;21(5):417-25.

221. Ionescu MA, Chene G, Robert G, et al. Anti-inflammatory mediators lipoxins and maresin upregulation by a topical amide in keratinocytes and dendritic cells and clinical application in a series of 72 cases of atopic dermatitis. Presented at 25th annual congress of the European Academy of Dermatology and Venereology; 2016; Vienna, EADV 2016.

222. Kim H, Ban J, Park MR, et al. Effect of bathing on atopic dermatitis during the summer season. Asia Pac Allergy. 2012;2(4):269-74.

223. Lisante TA, Mathes B, Zhang P, et al. Therapeutic benefits of an over-the-counter daily moisturizing $1 \%$ colloidal oatmeal cream on dry, itchy skin due to atopic dermatitis. J Am Acad Dermatol. 2015;72(5 Suppl 1):76.

224. Lynde CW, Andriessen A. A cohort study on a ceramide-containing cleanser and moisturizer used for atopic dermatitis. Cutis. 2014;93(4):207-13.

225. Meckfessel MH, Hernandez K, Pham H. Performance and parent satisfaction of a moisturizer used for atopic-prone babies and toddlers. J Am Acad Dermatol. 2017;76(6 Suppl 1):194.

226. Mochizuki H, Muramatsu R, Tadaki H, et al. Effects of skin care with shower therapy on children with atopic dermatitis in elementary schools. Pediatr Dermatol. 2009;26(2):223-5. 
227. Simpson E, Trookman NS, Rizer RL, et al. Safety and tolerability of a body wash and moisturizer when applied to infants and toddlers with a history of atopic dermatitis: results from an open-label study. Pediatr Dermatol. 2012;29(5):590-7.

228. Weber TM, Herndon JH Jr, Ewer M, et al. Efficacy and tolerability of steroid-free, over-the-counter treatment formulations in infants and children with atopic dermatitis. J Dermatol Nurses Assoc. 2015;7(1):17-24.

229. Agostinis F, Milani M. Barrier repair therapy in atopic eczema: efficacy of an isoleucine, rhamnosoft and niacinamide body cream. A pilot, prospective study. Presented at 24th annual congress of the European Academy of Dermatology and Venereology; 2015; Copenhagen, EADV 2015.

230. Mengeaud V, Phulpin C, Bacquey A, et al. An innovative oat-based sterile emollient cream in the maintenance therapy of childhood atopic dermatitis. Pediatr Dermatol. 2015;32(2):208-15.

231. Nocera T, Bacquey A, Rossi AB, et al. Tolerance and efficacy of a new emollient barrier cream in paediatric and adult population with mild to moderate atopic dermatitis. J Am Acad Dermatol. 2017;76(6 Suppl 1):261.

232. Seghers AC, Cai SC, Ho MS, et al. Evaluation of a pseudoceramide moisturizer in patients with mildto-moderate atopic dermatitis. Dermatol Ther (Heidelb). 2014;4(1):83-92.

233. Silverberg NB. A pilot trial of dermoscopy as a rapid assessment tool in pediatric dermatoses. Cutis. 2011;87(3):148-54.

234. Daehnhardt-Pfeiffer S, Surber C, Wilhelm KP, et al. Noninvasive stratum corneum sampling and electron microscopical examination of skin barrier integrity: pilot study with a topical glycerin formulation for atopic dermatitis. Skin Pharmacol Physiol. 2012;25(3):155-61.

235. Hon KL, Ching GK, Leung TF, et al. Estimating emollient usage in patients with eczema. Clin Exp Dermatol. 2010;35(1):22-6.

236. Koutroulis I, Pyle T, Kopylov D, et al. The association between bathing habits and severity of atopic dermatitis in children. Clin Pediatr (Phila). 2016;55(2):176-81.

237. Coutanceau C, Stalder JF. Analysis of correlations between patient-oriented SCORAD (PO-SCORAD) and other assessment scores of atopic dermatitis severity and quality of life. Dermatology. 2014;229(3):248-55.
238. Eberlein B, Eicke C, Reinhardt HW, et al. Adjuvant treatment of atopic eczema: assessment of an emollient containing $\mathrm{N}$-palmitoylethanolamine (ATOPA study). J Eur Acad Dermatol Venereol. 2008;22(1):73-82.

239. Hon KL, Wang SS, Lau Z, et al. Pseudoceramide for childhood eczema: does it work? Hong Kong Med J. 2011;17(2):132-6.

240. Virassamynaik S, Sayag M, Jourdan E. The interest of an emollient use during and after topical corticosteroid treatment in subjects with atopic dermatitis. Presented at 25th annual congress of the European Academy of Dermatology and Venereology; 2016; Vienna, EADV 2016.

241. Tiplica GS, Delarue A, Marinescu R, et al. Emollients in the management of atopic dermatitis in children: prevention of flares. Presented at 23rd annual congress of the European Academy of Dermatology and Venereology; 2014; Amsterdam, EADV 2014.

242. Wananukul S, Chatproedprai S, Chunharas A, et al. Randomized, double-blind, split-side, comparison study of moisturizer containing licochalcone A and $1 \%$ hydrocortisone in the treatment of childhood atopic dermatitis. J Med Assoc Thai. 2013;96(9):1135-42.

243. Frankel A, Sohn A, Patel RV, et al. Bilateral comparison study of pimecrolimus cream $1 \%$ and a ceramide-hyaluronic acid emollient foam in the treatment of patients with atopic dermatitis. J Drugs Dermatol. 2011;10(6):666-72.

244. Tsang YC, Hon KL, Pong NH, et al. Efficacy of sodium hypochlorite (bleach) baths to reduce Staphylococcus aureus colonization in patients with moderate-to-severe atopic dermatitis. Allergy. 2015;70(Suppl 101):81.

245. Gayraud F, Imko-Walczuk B, Sayag M, et al. Comparative, randomized, double-blinded study assessing the efficacy of a new kind of dermocosmetic product containing Skin Barrier Therapy $^{\circledR}$ on infants and children with moderate atopic dermatitis. J Dtsch Dermatol Ges. 2014;12(Suppl 2):14-5.

246. Ridd M, Gaunt DM, Garfield K, et al. Effectiveness and acceptability of four commonly used leave-on emollients in the treatment of childhood eczema. Br J Dermatol. 2016;175(Suppl S1):160.

247. Bianchi P, Theunis J, Casas C, et al. Effects of a new emollient-based treatment on skin microflora balance and barrier function in children with mild atopic dermatitis. Pediatr Dermatol. 2016;33(2):165-71. 
248. Giordano-Labadie F, Cambazard F, Guillet G, et al. Evaluation of a new moisturizer (Exomega milk) in children with atopic dermatitis. J Dermatol Treat. 2006;17(2):78-81.

249. Hlela C, Lunjani N, Gumedze F, et al. Affordable moisturisers are effective in atopic eczema: a randomised controlled trial. S Afr Med J. 2015;105(9):780-4.

250. Weber TM, Samarin F, Babcock MJ, et al. Steroidfree over-the-counter eczema skin care formulations reduce risk of flare, prolong time to flare, and reduce eczema symptoms in pediatric subjects with atopic dermatitis. J Drugs Dermatol. 2015;14(5):478-85.

251. Wong SM, Ng TG, Baba R. Efficacy and safety of sodium hypochlorite (bleach) baths in patients with moderate to severe atopic dermatitis in Malaysia. J Dermatol. 2013;40(11):874-80.

252. Sugarman JL, Parish LC. Efficacy of a lipid-based barrier repair formulation in moderate-to-severe pediatric atopic dermatitis. J Drugs Dermatol. 2009;8(12):1106-11.

253. Marseglia A, Licari A, Agostinis F, et al. Local rhamnosoft, ceramides and L-isoleucine in atopic eczema: a randomized, placebo controlled trial. Pediatr Allergy Immunol. 2014;25(3):271-5.

254. Weber TM, Samarin F, Babcock MJ, Filbry A, et al. A novel daily moisturizing cream for effective management of mild to moderate atopic dermatitis in infants and children. J Am Acad Dermatol. 2015;72(5 Suppl 1):AB73.

255. Grimalt R, Mengeaud V, Cambazard F, Study Investigators' Group. The steroid-sparing effect of an emollient therapy in infants with atopic dermatitis: a randomized controlled study. Dermatology. 2007;214(1):61-7.

256. Theunis J, Bianchi P, Villeneuve C, et al. Evaluation on clinical, functional and microbiological parameters of a novel emollient balm containing an Aquaphilus dolomiae extract in 1-to-4 years old children suffering from atopic dermatitis: international, multicenter, randomized versus control group. Presented at 23rd annual congress of the European Academy of Dermatology and Venereology; 2014; Amsterdam, EADV 2014.

257. Patrizi A, Capitanio B, Neri I, et al. A double-blind, randomized, vehicle-controlled clinical study to evaluate the efficacy and safety of MAS063DP (ATOPICLAIR) in the management of atopic dermatitis in paediatric patients. Pediatr Allergy Immunol. 2008;19(7):619-25.

258. Stainer R, Matthews S, Arshad SH, et al. Efficacy and acceptability of a new topical skin lotion of sodium cromoglicate (Altoderm) in atopic dermatitis in children aged 2-12 years: a double-blind, randomized, placebo-controlled trial. $\mathrm{Br} \mathrm{J}$ Dermatol. $2005 ; 152(2): 334-41$.

259. Tripodi S, Di Rienzo Businco A, Panetta V, et al. Lack of efficacy of topical furfuryl palmitate in pediatric atopic dermatitis: a randomized doubleblind study. J Investig Allergol Clin Immunol. 2009;19(3):204-9.

260. Boralevi F, Saint Aroman M, Delarue A, et al. Longterm emollient therapy improves xerosis in children with atopic dermatitis. J Eur Acad Dermatol Venereol. 2014;28(11):1456-62.

261. Gayraud F, Sayag M, Jourdan E. Efficacy and tolerance assessment of a new type of dermocosmetic in infants and children with moderate atopic dermatitis. J Cosmet Dermatol. 2015;14(2):107-12.

262. Korting HC, Schollmann C, Cholcha W, Collaborative Study Group, et al. Efficacy and tolerability of pale sulfonated shale oil cream $4 \%$ in the treatment of mild to moderate atopic eczema in children: a multicentre, randomized vehicle-controlled trial. J Eur Acad Dermatol Venereol. 2010;24(10): 1176-82.

263. Patrizi A, Raone B, Neri I, et al. Randomized, controlled, double-blind clinical study evaluating the safety and efficacy of MD2011001 cream in mild-tomoderate atopic dermatitis of the face and neck in children, adolescents and adults. J Dermatol Treat. 2016;27(4):346-50.

264. Hajar T, Hanifin JM, Tofte SJ, et al. Prehydration is effective for rapid control of recalcitrant atopic dermatitis. Dermatitis. 2014;25(2):56-9.

265. Taieb C, Delas M. Evaluation of 2 different drug related in atopic dermatitis managements. Presented at 23rd annual congress of the European Academy of Dermatology and Venereology; 2014; Amsterdam, EADV 2014.

266. Barbarot S, Aubert H, Stalder J-F. How patient-reported outcomes can be useful in routine practice in children with atopic dermatitis? Pediatr Dermatol. 2016;33(Suppl 1):S46.

267. Kircik LH, Del Rosso JQ. Nonsteroidal treatment of atopic dermatitis in pediatric patients with a ceramide-dominant topical emulsion formulated with an optimized ratio of physiological lipids. J Clin Aesthet Dermatol. 2011;4(12):25-31.

268. Ong PY, Ferdman RM, Dunaway T, et al. Downregulation of atopic dermatitis-associated serum chemokines by wet-wrap treatment: a pilot study. Ann Allergy Asthma Immunol. 2008;100(3):286-7. 
269. Hon KL, Wong KY, Cheung LK, et al. Efficacy and problems associated with using a wet-wrap garment for children with severe atopic dermatitis. J Dermatol Treat. 2007;18(5):301-5.

270. Nicol NH, Boguniewicz M, Strand M, et al. Wet wrap therapy in children with moderate to severe atopic dermatitis in a multidisciplinary treatment program. J Allergy Clin Immunol Pract. 2014;2(4): 400-6.

271. Hindley D, Galloway G, Murray J, et al. A randomised study of wet wraps versus conventional treatment for atopic eczema. Arch Dis Child. 2006;91(2):164-8.

272. Yun Y, Lee S, Kim S, et al. Inpatient treatment for severe atopic dermatitis in a Traditional Korean Medicine hospital: introduction and retrospective chart review. Complement Ther Med. 2013;21(3): 200-6.

273. Baltas E, Csoma Z, Bodai L, et al. Treatment of atopic dermatitis with the xenon chloride excimer laser. J Eur Acad Dermatol Venereol. 2006;20(6):657-60.

274. Darne S, Leech SN, Taylor AE. Narrowband ultraviolet B phototherapy in children with moderate-tosevere eczema: a comparative cohort study. Br J Dermatol. 2014;170(1):150-6.

275. Cameron H, Yule S, Dawe RS, et al. Review of an established UK home phototherapy service 1998-2011: improving access to a cost-effective treatment for chronic skin disease. Public Health. 2014;128(4):317-24.

276. Clayton TH, Clark SM, Turner D, et al. The treatment of severe atopic dermatitis in childhood with narrowband ultraviolet B phototherapy. Clin Exp Dermatol. 2007;32(1):28-33.

277. Jury CS, McHenry P, Burden AD, et al. Narrowband ultraviolet B (UVB) phototherapy in children. Clin Exp Dermatol. 2006;31(2):196-9.

278. Mamtora A, Gambles BJ, Lloyd A, et al. Phototherapy for paediatric dermatoses: data from a singlecentre retrospective survey. $\mathrm{Br} \mathrm{J}$ Dermatol. 2016;175(Suppl S1):164.

279. Pavlovsky M, Baum S, Shpiro D, et al. Narrow band UVB: is it effective and safe for paediatric psoriasis and atopic dermatitis? J Eur Acad Dermatol Venereol. 2011;25(6):727-9.

280. Tan E, Lim D, Rademaker M. Narrowband UVB phototherapy in children: a New Zealand experience. Australas J Dermatol. 2010;51(4):268-73.

281. Tekin B, Gencosmanoglu DS, Yucelten D, et al. Safe and effective use of photo(chemo)therapy in children: a single-center retrospective review. Pediatr Dermatol. 2016;33(Suppl 1):S20-1.

282. Mok ZR, Koh MJ, Chong WS. Is phototherapy useful in the treatment of atopic dermatitis in asian children? A 5-year report from Singapore. Pediatr Dermatol. 2014;31(6):698-702.

283. Patrizi A, Savoia F, Giacomini F, et al. The effect of summer holidays and sun exposure on atopic dermatitis. G Ital Dermatol Venereol. 2009;144(4): 463-6.

284. He A, Feldman SR, Fleischer AB. Trends in atopic dermatitis management: comparison of 1990-1997 to 2003-2012. J Drugs Dermatol. 2018;17(2): $135-40$.

285. Eichenfield LF, Boguniewicz M, Simpson EL, et al. Translating atopic dermatitis management guidelines into practice for primary care providers. Pediatrics. 2015;136(3):554-65.

286. Bath-Hextall FJ, Birnie AJ, Ravenscroft JC, et al. Interventions to reduce Staphylococcus aureus in the management of atopic eczema: an updated Cochrane review. Br J Dermatol. 2010;163(1):12-26.

287. Schmitt J, Buske-Kirschbaum A, Tesch F, et al. Increased attention-deficit/hyperactivity symptoms in atopic dermatitis are associated with history of antihistamine use. Allergy. 2018;73(3):615-26.

288. Simpson EL, Berry TM, Brown PA, et al. A pilot study of emollient therapy for the primary prevention of atopic dermatitis. J Am Acad Dermatol. 2010;63(4):587-93.

289. Simpson EL, Chalmers JR, Hanifin JM, et al. Emollient enhancement of the skin barrier from birth offers effective atopic dermatitis prevention. J Allergy Clin Immunol. 2014;134(4):818-23.

290. Dizon MP, Yu AM, Singh RK, et al. Systematic review of atopic dermatitis disease definition in studies using routinely collected health data. $\mathrm{Br} \mathrm{J}$ Dermatol. 2018. https://doi.org/10.1111/bjd.16340.

291. Protopic ${ }^{\circledR}$ (tacrolimus) ointment $0.03 \%$ and ointment $0.1 \%$ (US package insert). Northbook: Astellas Pharma US, Inc. 2012.

292. Nankervis H, Thomas KS, Delamere FM, et al. What is the evidence base for atopic eczema treatments? A summary of published randomized controlled trials. Br J Dermatol. 2017;176(4):910-27.

293. Williams HC. Strengths and limitations of evidencebased dermatology. Indian J Dermatol. 2014;59(2):127-33. 